\title{
Microbial communities of subtidal shallow sandy sediments change with depth and wave disturbance, but nutrient exchanges remain similar
}

\author{
Hugh I. Forehead ${ }^{1,2,3, *}$, Peter A. Thompson ${ }^{1}$ \\ ${ }^{1}$ CSIRO Division of Marine and Atmospheric Research, GPO Box 1538, Hobart, Tasmania 7001, Australia \\ ${ }^{2}$ School of Plant Biology, 35 Stirling Highway, Crawley, Western Australia 6009, Australia \\ ${ }^{3}$ Present address: Cellana LLC, 73-4460 Queen Kaahumanu Highway, Kailua-Kona, Hawaii 97640, USA
}

\begin{abstract}
Along 3 replicate transects, sediments were sampled from a subtidal sandbank in Cockburn Sound, Western Australia, at 4 depths: 1.5, 4 and $8 \mathrm{~m}$ and at $14 \mathrm{~m}$ on the flat at the base of the bank. Pulse amplitude modulated (PAM) fluorescence, fluxes of oxygen and inorganic nutrients, $\mathrm{N}_{2}$ fixation and denitrification were measured and sediments analysed for granulometry, pigments, fatty acids, neutral lipids, organic $\mathrm{C}$ and total $\mathrm{N}$. There were 2 functional depth zones: $1.5 \sim<4$, and $\geq 4 \mathrm{~m}$. At $1.5 \mathrm{~m}$, chl a concentration was $42.3 \mathrm{mg} \mathrm{m}^{-2}(1.83 \mathrm{SE}, \mathrm{n}=12)$, sediments were net heterotrophic, and there were effluxes of inorganic nutrients in the light and uptake in the dark. The 2 intermediate depths had benthic microalgal (BMA) biomass around $88 \mathrm{mg} \mathrm{m}^{-2} \mathrm{chl} a_{\text {, }}$ and mean gross primary productivity of $2.23 \mathrm{mmol} \mathrm{O}_{2} \mathrm{~m}^{-2} \mathrm{~h}^{-1}$. At $14 \mathrm{~m}$, chl a concentration was $75 \mathrm{mg} \mathrm{m}^{-2}$, and sediments were net autotrophic. Sediment-water exchanges of inorganic nutrients were dominated by $\mathrm{NH}_{4}$, with maximum efflux from the sediment $\left(1044 \mu \mathrm{mol} \mathrm{m}^{-2} \mathrm{~d}^{-1}\right)$ at $8 \mathrm{~m}$ and maximum uptake $\left(539 \mu \mathrm{mol} \mathrm{m}{ }^{-2}\right.$ $\mathrm{d}^{-1}$ ) at $4 \mathrm{~m}$. At $1.5 \mathrm{~m}$ depth, there was a marked discontinuity in most parameters as the microbial community metabolism and cycling of nutrients between the sediment and water column were altered in conditions of more frequent wave disturbance. At depths $\geq 4 \mathrm{~m}$, we observed greater amounts of biomass and more primary productivity, but net exchanges of inorganic nutrients were remarkably consistent at all depths from 1.5 to $14 \mathrm{~m}$.
\end{abstract}

KEY WORDS: Microphytobenthos - Benthic microalgae - Biomarkers - Lipids · Pigments · Biogeochemistry · Resuspension

Resale or republication not permitted without written consent of the publisher

\section{INTRODUCTION}

Sandy sediments occupy large areas of coastal waters (Emery 1968), and can be productive over large areas of continental shelves (Cahoon et al. 1994). The benthic microalgae (BMA) in these sediments contribute to food webs and have important functions in nutrient cycling in coastal ecosystems (MacIntyre et al. 1996). The waters of the west coast of Australia are subject to the warm, oligotrophic Leeuwin Current (Pearce 1991). There is little or no upwelling along this coast and negligible freshwater input in summer, resulting in conditions of low productivity (Pearce et al.
2006). During summer, the water column dissolved inorganic nitrogen (DIN) concentrations are extremely low, $<0.2 \mu \mathrm{mol} \mathrm{l}^{-1}$ (Thompson \& Waite 2003), and primary productivity on the continental shelf is hypothesised to be limited by the resupply of DIN from sediments (K. Wild-Allen \& M. Feng unpubl.).

Hydrodynamic energy of the water column can have important effects on the benthic microbial community. For example, resuspension of sediments frequently causes loss of microalgal biomass by removal of cells (Baillie \& Welsh 1980, Blanchard et al. 2001). Conversely, shelter from physical disturbance results in increased BMA biomass (Plante et al. 1986). The sedi- 
ment grain size is generally proportional to the degree of physical disturbance (de Jong \& de Jonge 1995), and an inverse relationship between grain size and biomass of diatoms has been shown (Cahoon et al. 1999, Watermann et al. 1999). Coarse sediments with strong advective porewater flows can trap organic matter (OM) and rapidly degrade it, leading to high rates of turnover (Rasheed et al. 2003). Bacteria are a vital part of the sediment microbial community and are influenced by water movement. In flume experiments, the heterotrophic fraction of the sediment community was found to be more easily removed by water flows than BMA (Shimeta et al. 2002). Similarly, the numbers of bacteria were found to be inversely related to the grain size of the sediments on a tidal flat in Nova Scotia, Canada (Dale 1974).

The uptake of nutrients from the water column is affected by the ratio of the autotrophic to the heterotrophic fraction of the sediment microbial community (Nilsson et al. 1991, Engelsen et al. 2008). There is a tendency to greater uptake with autotrophic dominance, and release with greater heterotrophy. The ratio is a function of irradiance, autotrophic biomass and OM concentration (Rizzo et al. 1996), and shifts in the ratio may occur at different depths in different environments. In the productive waters of a Swedish fjord, a light gradient resulted in a transition from autotrophic to heterotrophic dominance at a depth of only $5 \mathrm{~m}$ (Sundbäck et al. 2004). In the clearer waters off North Carolina, USA, sediments became net heterotrophic at $15 \mathrm{~m}$, although BMA biomass extended to a depth of $41 \mathrm{~m}$ (Cahoon \& Cooke 1992).

Much of the work on the ecology and biogeochemistry of subtidal sediments has been done in cool (Cahoon et al. 1993, Böer et al. 2008), more eutrophic (Lukatelich \& McComb 1986) and more sheltered waters (e.g. Blanchard 1990), and the coast of Western Australia provides a useful contrast. Here we examined the effect of a depth gradient on subtidal sandy sediments from near the surface to $14 \mathrm{~m}$ depth in a relatively exposed, warm and oligotrophic environment. We hypothesised that variation in light and wave energy would affect BMA biomass in these shallow sandy sediments. In addition, we hypothesised that the ratio of microbial autotrophs to heterotrophs would decrease with depth, with the decreasing autotrophic dominance resulting in a decline in net primary productivity (NPP) and a reduction in the uptake of inorganic nutrients.

\section{MATERIALS AND METHODS}

Location. Cockburn Sound is a sandy basin on the west coast of Western Australia (Fig. 1). The sound is
$16 \mathrm{~km}$ long by $9 \mathrm{~km}$ wide, and the depth of the central flat ranges from 16 to $22.1 \mathrm{~m}$ (Australian Hydrographic Service 2001). It is enclosed to the east and south by a coastline of carbonate sand beaches and limestone headlands. The western border is formed by subtidal sandbanks, rocky reefs, Garden Island and the causeway that joins the island to Cape Peron. Transects for this study were on the southern side of the subtidal Parmelia Bank (32 $\left.{ }^{\circ}{ }^{\prime} \mathrm{S}, 115^{\circ} 43^{\prime} \mathrm{E}\right)$, which joins Woodman Point to make the northern border of the sound. Parmelia Bank sediments are comprised of at least $50 \%$ calcium carbonate (shell fragments, mainly foraminifera and molluscs), quartz and minor amounts of feldspar (Brachmanis 2002). The area is microtidal (range 0.1 to $0.9 \mathrm{~m}$ ), and water temperatures range from $\sim 15^{\circ}$ to $24^{\circ} \mathrm{C}$ over an annual cycle (Western Australia Department of Environmental Protection 1996).

Collection of samples. Three transects, $50 \mathrm{~m}$ apart running north-south down Parmelia Bank (Fig. 1), were sampled at depths of 1.5 (top of bank), 4, 8 and $14 \mathrm{~m}$ (sandflat at the base of the bank) by SCUBA divers. Intact sediment cores $(50 \mathrm{~mm}$ diameter, 3 depth $^{-1}$ transect $^{-1}$ ) were collected for ex situ incubations to measure fluxes of oxygen and inorganic nutrients, fluorescence, $\mathrm{N}_{2}$ fixation and denitrification. Sample collection was carried out in summer, on 2 and 9 February 2004. Equipment and manpower constraints required 2 visits. All samples and cores were collected on the first occasion except for the cores used to measure denitrification. Weather and sea conditions were similar between the 2 trips.

Material for pigment analysis was taken from the same cores that were used for oxygen, nutrient and $\mathrm{N}_{2}$ fixation fluxes immediately after flux measurements were completed. The top $5 \mathrm{~mm}$ of the sediment was removed and gently homogenised, and subsamples were placed in cryogenic vials and then into liquid $\mathrm{N}_{2}$ $\left(-176^{\circ} \mathrm{C}\right)$. Because of the amount of material needed, samples for bulk sediment parameters (granulometry, lipids and \% $\mathrm{C}$ and $\% \mathrm{~N}$ content) were harvested from the top $5 \mathrm{~mm}$ of sediment extruded from separate $100 \mathrm{~mm}$ diameter cores. These samples were collected into solvent-rinsed glass jars and kept frozen at $-20^{\circ} \mathrm{C}$.

For flux measurements, sediment cores were carefully collected without visibly disturbing the sediment surface and transported to the laboratory in cooled insulated containers. In the laboratory, cores were kept submerged in recirculated, filtered $(2 \mu \mathrm{m})$ site water, at an in situ temperature of $24^{\circ} \mathrm{C}$ and photosynthetically active radiation (PAR) of $500 \mu \mathrm{mol}$ of photons $\mathrm{m}^{-2} \mathrm{~s}^{-1}$ during the simulated in situ photoperiod of 13.5/10.5 h light/dark. We chose $500 \mu \mathrm{mol}$ of photons $\mathrm{m}^{-2} \mathrm{~s}^{-1}$, as it was measured at intermediate depths in this region, and it was considered sufficient to saturate photosynthesis based on pulse amplitude modulated (PAM) flu- 


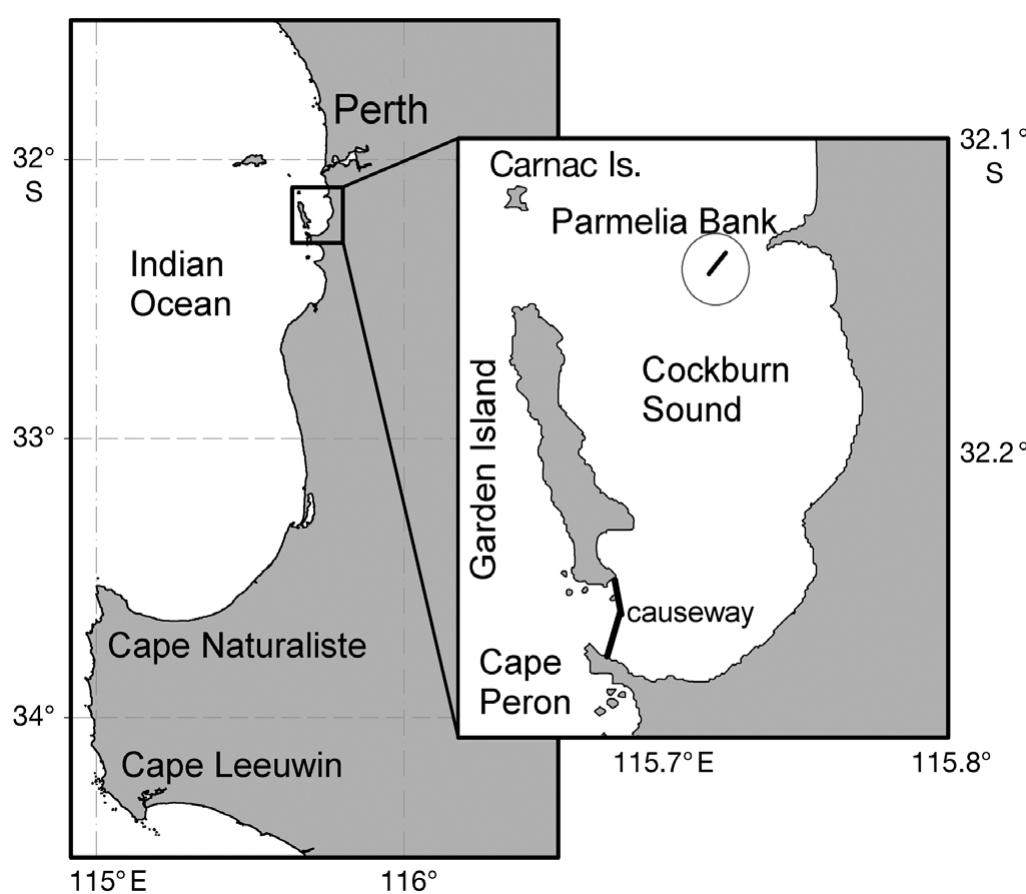

Fig. 1. Location of Cockburn Sound relative to the city of Perth, Western Australia. Inset: Circle denotes study site at the southern side of the Parmelia Bank

orescence measurements (Forehead 2006). Cores were very gently stirred with individual Teflon-coated magnetic stirrer bars (25 mm long), suspended $\sim 50 \mathrm{~mm}$ above the sediment and driven by an external magnet rotating at $60 \mathrm{rpm}$, a rate used in studies of these processes elsewhere (Dalsgaard et al. 2000, Cook et al. 2004 b). This speed was sufficient to circulate the water without causing any visible disturbance of the sediment surface. Cores were allowed to equilibrate in the laboratory for at least $6 \mathrm{~h}$ before flux measurements commenced. During the flux measurements, dissolved oxygen (DO) concentrations in capped cores were allowed to deviate by no more than $20 \%$ from initial values. Measurements of fluxes across the sediment-water interface in illuminated cores were carried out during in situ daytime and in darkened cores at night, to capture any existing endogenous diurnal patterns. Water samples were immediately filtered through pre-combusted Whatman GF/F filters into $10 \mathrm{ml}$ polypropylene tubes, and frozen at $-20^{\circ} \mathrm{C}$. Nutrient analysis was carried out within 8 mo of sample collection.

Site measurements. PAR was measured with a Li-Cor LI-192SA $\pi\left(180^{\circ}\right)$ sensor attached to a LI250A PAR meter (Li-Cor Biosciences). Salinity, DO and temperature were measured with a Yeo-Cal model 611 Intelligent Water Quality Analyser (YeoKal Electronics).
Grain sizing. Sediments from each site were dried at $50^{\circ} \mathrm{C}$ and weighed before wet sieving through an 11-sieve stack (2360 to $45 \mu \mathrm{m}$ ). The sieves containing the sediments were then dried at room temperature, and the sediment fractions were weighed. Median grain size was calculated from the cumulative weight plot using the 11 size classes on the $x$-axis and \% of total on the $y$-axis. The degree of sorting was calculated using the inclusive graphic quartile deviation index (QDI; Giere et al. 1988):

$$
\mathrm{QDI}=\frac{\varphi 84-\varphi 16}{4}+\frac{\varphi 95-\varphi 5}{6.6}
$$

where $\varphi=-\log _{2}$ (grain size in $\left.\mu \mathrm{m}\right), \varphi x$ is the $\varphi$ value of the $x$ th percentile of the cumulative weight plot. The results for sediment grain size at different depths were classified into 1 of 7 categories based on their degree of sorting.

Organic carbon (OC), nitrogen. Sediment samples were freeze-dried and ground to a powder with a mortar and pestle. For OC analysis, $4 \mathrm{mg}$ samples were weighed into aluminium cups (Elemental Microanalysis); for $\mathrm{N}$ analysis, sample weight was $40 \mathrm{mg}$ and tin cups (Elemental Microanalysis) were used. Before analysis for OC, samples were sequentially acidified with sulphurous acid to remove carbonate (Nieuwenhuize et al. 1994) and dried in an oven at $50^{\circ} \mathrm{C}$. Sediment samples for nitrogen analysis were weighed into tin cups. Samples were analysed for nitrogen and carbon contents using a Carlo Erba NA1500 CNS analyser interfaced via a Conflo II to a Finnigan Mat Delta S isotope-ratio mass spectrometer operating in the continuous-flow mode. Combustion and oxidation were achieved at $1090^{\circ} \mathrm{C}$ and reduction at $650^{\circ} \mathrm{C}$. Where necessary (because of high carbon contents) the carbon signal was quantitatively diluted with helium.

Lipids. Sediment samples were extracted 3 times by a 1-phase dichloromethane-methanol-water mixture (3:6:1 v:v:v) according to a modified version of the method of Bligh \& Dyer (1959). An aliquot of the total extract was saponified with $3 \mathrm{ml}$ of $5 \% \mathrm{KOH}$ in methanol:water $(80: 20)$ and heated at $80^{\circ} \mathrm{C}$ for $2 \mathrm{~h}$. The neutral lipid fraction was extracted into hexane:chloroform (4:1) (this mixture of solvents was used for the remainder of the extractions), then acidified and the fatty acid (FA) fraction extracted. The neutral (minus FAs) fraction was treated with bis(trimethylsilyl) trifluoroacetamide (BSTFA), $100 \mu \mathrm{l}$ at $60^{\circ} \mathrm{C}$ for $2 \mathrm{~h}$ to con- 
vert hydroxylated compounds such as sterols and alcohols to their trimethylsilyl (TMSi) ethers. The FA fraction was treated with $\mathrm{MeOH}: \mathrm{HCl}: \mathrm{CHCl}_{3}$ (10:1:1) at $80^{\circ} \mathrm{C}$ for $2 \mathrm{~h}$, and the resulting FA methyl esters were extracted. Initial gas chromatography (GC) was performed using a Varian CP 3800. Analysing the residual neutral fraction, the GC was equipped with a $50 \mathrm{~m} \times$ $0.32 \mathrm{~mm}$ i.d. cross-linked $5 \%$ phenyl-methyl silicone (HP5, Hewlett Packard), fused-silica capillary column. The FA fraction (as methyl esters) was analysed on the same instrument, except that a septum programmable injector (SPI) was used with the capillary column (Hewlett Packard HP1: fused-silica, $50 \mathrm{~m} \times 0.32 \mathrm{~mm}$ i.d. cross-linked $1 \%$ phenyl-methyl silicone). Sterol and FA fractions were analysed using a flame ionisation detector (FID), with $5 \beta(\mathrm{H})$-cholestan-24-ol as the internal standard for sterols and the methyl ester of tricosanoic acid as the internal standard for FA. Peak identifications were based on retention times relative to authentic and laboratory standards and subsequent combined GC and mass spectrometer (GC-MS) analysis. The detection limit for individual sterols and FAs was $\sim 0.2 \mathrm{mg} \mathrm{m}^{-2}$ of $5 \mathrm{~mm}$ deep sediment. Individual sterols and FAs were identified by GC-MS analyses performed on a Thermoquest/Finnigan GCQ-Plus bench-top mass spectrometer fitted with a direct capillary inlet and an automated on-column injector. Data were acquired in scan acquisition or selective ion monitoring. The nonpolar column (HP5) and operating conditions were the same as that described above for the GC-FID analyses, except that helium was used as the carrier gas.

Samples of Halophila ovalis were collected from near Cockburn Sound and frozen in liquid $\mathrm{N}_{2}$ until analysis. Leaves were cut into pieces and macerated with a mortar and pestle in the same dichloromethanemethanol-water mixture that was used for the sediments. The remainder of the analyses were performed as above.

For sediment community analysis, biomarkers were used to quantify the major classes of micro-organisms. Specific FAs were ascribed to the following taxonomic or functional groups: diatoms, chlorophytes, cyanophytes, bacteria and heterotrophs (Table S1 in the supplement at www.int-res.com/articles/suppl/m414 p011_supp.pdf) and neutral lipid as autotrophs, BMA, heterotrophs, seagrass and bacteria (Table S2) as per references cited. The classification 'heterotrophs' encompassed any non-photosynthetic organisms (e.g. heterotrophic bacteria, protozoa, fungi or fauna) found in the sediment. We considered 15:0 FA separately from the other bacterial FAs because of its large concentrations and potentially ambiguous origins (mostly bacterial, Sass et al. 2002; but also in diatoms, Dunstan et al. 1993), so it was not included in estimates of bac- terial biomass. FAs used to calculate total BMA FAs were: $14: 0,16: 4,16: 1 \omega 9,16: 1 \omega 7,16: 0,18: 2 \omega 6,18: 4 \omega 3$,

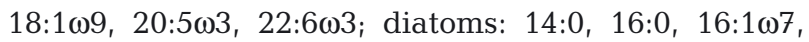
20:5 $\omega 3$. These latter assignations were made based on the ratios in which they presented (particularly the ratio of $16: 0$ to $16: 1 \omega 7$ ) and in conjunction with other biomarkers and microscopy. Quantities of some other BMA FAs were probably also from diatoms, but their proportions were not known. The chlorophyte (green algae) FAs could also be found in some other classes, so assignations to that class were made in conjunction with pigments (chl $b$, lutein; Jeffrey et al. 1997).

Sterols are referred to by their trivial names for ease of reading, i.e. cholesta-5, 22E-dien-3 $\beta$-ol as 22-dehydrocholesterol; cholest-5-en-3 $\beta$-ol as cholesterol; 24-methylcholesta-5, 22E-dien-3 $\beta$-ol as brassicasterol; 24-methylcholesta-5, 24(28)-dien-3 3 -ol as 24-methylenecholesterol; 24-methylcholest-5-en-3 $\beta$-ol as campesterol; 24-ethylcholesta-5, 22E-dien-3 $\beta$-ol as stigmasterol; 24 -ethylcholest-5-en-3 $\beta$-ol as sitosterol; and $4 \alpha, 23$, 24 -trimethyl-5 $\alpha$-cholest-22E-en-3 $\beta$-ol as dinosterol.

The conversion of stenols to stanols (hydrogenation of the delta 5 bond) is an early step in the process of diagenesis of stenols. Thus we used the stanol:stenol ratio as an index of bacterial reprocessing and grazing by metazoans (Gagosian et al. 1980, Jaffe et al. 2001).

Pigments. Sediments were extracted twice in $100 \%$ acetone at $4^{\circ} \mathrm{C}(18$ and $4 \mathrm{~h})$. Following extraction, water was added to give a ratio of 9:1 acetone:water by volume, and filtered $(0.2 \mu \mathrm{m}$ membrane filter; Whatman Anatop) before analysis by a Waters high performance liquid chromatograph (HPLC), comprising a model 600 controller, 717 plus refrigerated auto-sampler, and a 996 photodiode array detector. Pigments were separated as described by Wright et al. (1991), detected at $436 \mathrm{~nm}$, and identified against standard spectra. Concentrations of chl $a_{\text {, }} \operatorname{chl} b, \beta, \beta$-carotene, and $\beta, \varepsilon$-carotene in sample chromatograms were determined from standards, and all other pigment concentrations were determined from standards of purified pigments isolated from algal cultures. Information for the assignation of microalgal marker pigments was drawn from Jeffrey et al. (1997).

The phaeopigments: chlorophyll ratio has been used to indicate the physiological or grazing state of a BMA community (Bidigare et al. 1986, Mundree et al. 2003). In this study, phaeophytin $a$ and pyrophaeophytin $a$ were the only degraded pigments that could be distinctly and reliably separated; therefore, the ratio of (phaeophytin $a+$ pyrophaeophytin a) to chl a was used.

Nutrient fluxes. Incubations ranged from 2 to $3 \mathrm{~h}$, depending on the rates of change of DO concentrations (to keep within the limit of a $20 \%$ increase or decrease). Inorganic nutrients were analysed on a Lachat 
8000QC flow injection system. $\mathrm{NO}_{2}{ }^{-}, \mathrm{NO}_{3}{ }^{-}$and $\mathrm{PO}_{4}{ }^{-}$ were analysed by Lachat standard methods. $\mathrm{NH}_{4}{ }^{+}$was analysed using $o$-phthalaldialdehyde (OPA) derivatisation and fluorescence detection as described by Watson et al. (2005), except that the oven temperature was set at $50^{\circ} \mathrm{C}$. Reference standards were from Ocean Scientific International (Petersfield, UK).

Flux rates were calculated as:

$$
\text { rate }=\frac{\Delta[n] \times v}{A}
$$

where $\Delta[n]$ is the change in concentration of inorganic nutrient(s) over the incubation period, $V$ is the volume of the water column in the core, and $A$ is the crosssectional area of the sediment surface. Hourly flux rates were extrapolated to $24 \mathrm{~h}$ rates as follows: fluxes in the light were multiplied by the interval over which PAR was at or above optimal irradiance for diatoms (using $\mathrm{I}_{\text {opt }}$ values measured with PAM fluorometry; see below). These intervals were adjusted for depth by multiplying PAR by the depth in $m$ and a locally determined attenuation factor $\left(K_{\mathrm{d}}\right)$ of $0.18 \mathrm{~m}^{-1}$ (Thompson \& Waite 2003); the resulting periods were $13.4 \mathrm{~h}$ at $1.5 \mathrm{~m}, 13.3 \mathrm{~h}$ at $4 \mathrm{~m}$, $12.4 \mathrm{~h}$ at $8 \mathrm{~m}$, and $9.8 \mathrm{~h}$ at $14 \mathrm{~m}$. PAR through the day was modelled by a sinusoidal function, based on irradiance data from nearby Hope Valley (Mountford \& Greico 2002). Flux rates from darkened cores were multiplied by the remainder of the $24 \mathrm{~h}$. A value of $K_{\mathrm{d}}=0.108$ (P. Thompson unpublished data) was used to estimate the light climate in deeper waters.

Oxygen fluxes. Cores for oxygen flux analyses were measured for dissolved oxygen (DO) with a calibrated WTW Oxi 440 probe (precision $\pm 5 \%$ ). The tops of the cores were raised above the surrounding water level and capped with watch glasses, and any bubbles were carefully removed. Measurements of [DO] were made at the beginning and end of incubations, and the rate of oxygen increase or decrease was calculated as:

$$
\text { rate }=\frac{\Delta\left[\mathrm{O}_{2}\right] \times V}{A}
$$

Symbols are the same as for nutrient flux calculation. The rate of oxygen evolution during the day was used as a measure of NPP; oxygen uptake in the dark was used for community respiration (CR). Gross primary productivity (GPP) was calculated as the sum of NPP and CR.

To test for linearity, 4 measurements were made through the course of incubations for different sediments, and the fit to a straight line was consistently good $\left(R^{2} \geq 0.98\right)$. Rates of NPP over $24 \mathrm{~h}$ were calculated by the same method used for nutrient fluxes (see above).

PAM fluorometry. Fluorescence parameters of BMA communities were measured from intact cores with a Phyto PAM 4 channel fluorometer (Heinz Walz GmbH) fitted with a Phyto-EDF fibre-optic attachment, designed for use on biofilms. The 4 -channel fluorometer allows simultaneous measurements from 3 taxa with substantially different pigments. Microalgal cultures from the CSIRO Collection of Living Microalgae were used to calibrate the taxonomic discrimination of the measuring software (Phyto-Win v1.46, Heinz Walz). The cultures used were: brown, Navicula jeffreyi (CS-46); green, Dunaliella sp. (CS-353); and bluegreen, Oscillatoria sp. (CS-52). Given the reference spectra used in the Phyto PAM, 'browns' are approximately equivalent to any species with chl $c$ (referred to hereafter as browns), greens would contain chl $b$ ('greens') and cyanophytes would contain zeaxanthin ('blue-greens'). All fluorescence terminology is consistent with Büchel \& Wilhelm (1993). Measurement light was supplied at $25 \mathrm{~Hz}$ or $12 \mu$ s pulses at 4 wavelengths $(470,520,645,665 \mathrm{~nm})$ to determine $F_{\mathrm{o}}$ (the initial minimal fluorescence yield). Saturating irradiance pulses of $0.2 \mathrm{~s}$ duration at $2600 \mu \mathrm{mol} \mathrm{m} \mathrm{m}^{-2} \mathrm{~s}^{-1}$ were applied in conjunction with increased actinic light at $1,32,64,90$, $150,240,320,405,480$ and $610 \mu \mathrm{mol} \mathrm{m}^{-2} \mathrm{~s}^{-1}$ to provide estimates of relative electron transport rates (ETR) which were used to construct rapid light curves and fit to the model of Eilers \& Peeters (1988) to estimate photosynthetic parameters $\mathrm{ETR}_{\max }$ (maximum electron transport rate), $I_{\text {opt }}$ (optimal irradiance $=$ that which saturated ETR), and alpha ( $\alpha=$ initial slope of irradiance versus ETR curve). The average instrument gain was 20.3 and ranged from 17 to 24 . The active fluorescence $(\Delta F)$ is the difference between the fluorescence yield from a repeated saturating pulse (maximum yield, $F_{\mathrm{m}}$ ) and the yield in the near dark $\left(F_{0}\right)$ after Brack \& Frank (1998),

$$
\Delta F=\left(F_{\mathrm{m}}-F_{\mathrm{o}}\right)
$$

and provides a precise measure of relative biomass in the 3 different taxa.

The effective quantum yield of photochemical energy conversion in photosystem II (PSII) was defined after Genty et al. (1989) as:

$$
\theta_{\mathrm{PSII}}=\left(F_{\mathrm{m}^{\prime}}-F\right) / F_{\mathrm{m}^{\prime}}
$$

Denitrification. Denitrification was measured by the isotope pairing method (Nielsen 1992). A time series of 4 (independent) cores was used for illuminated (as for oxygen fluxes) and dark (wrapped in aluminium foil) incubations for each depth. In the same manner as the nutrient fluxes, cores were stirred by magnets suspended $\sim 50 \mathrm{~mm}$ above the sediment rotating at $\sim 60 \mathrm{rpm}$. Experiments commenced with the addition of stock ${ }^{15} \mathrm{NO}_{3}{ }^{-}$to a final concentration of $\approx 60 \mu \mathrm{M}$ in the water column over the sediment. This concentration was chosen after a series of experiments (as described by Rysgaard et al. 1995) had shown that 
concentrations of ${ }^{15} \mathrm{NO}_{3}{ }^{-}$above $40 \mu \mathrm{M}$ gave constant values of denitrification. Samples were taken for analysis of total $\mathrm{NO}_{3}{ }^{-}$before and after the addition of ${ }^{15} \mathrm{NO}_{3}{ }^{-}$in order to calculate final ${ }^{15} \mathrm{~N}$ enrichment. Cores were then capped and left for $2 \mathrm{~h}$ to allow the added ${ }^{15} \mathrm{NO}_{3}{ }^{-}$to diffuse into the denitrification zone and attain equilibrium. Cores were sacrificed over a time span that allowed the DO to decrease by no more than $20 \%$ below saturation. They were sacrificed as follows: $1 \mathrm{ml}$ of $50 \% \mathrm{ZnCl}_{2}$ was added to the water overlying the sediment, and the sediment was gently homogenised with the water column using a metal rod; coarser particles were allowed to settle for about 1 min before a sample of about $40 \mathrm{ml}$ was taken using a gas-tight syringe. The sample was then placed in a $12 \mathrm{ml}$ Exetainer (Labco) to which $250 \mu \mathrm{l}$ of $50 \% \mathrm{w} / \mathrm{v} \mathrm{ZnCl}_{2}$ had been added. A headspace of $\mathrm{He}$ was introduced into the Exetainers within $2 \mathrm{wk}$, and the gas samples were subsequently analysed for the isotopic composition of the $\mathrm{N}_{2}$ gas within several months. The gas was analysed using a Carlo Erba NA1500 CNS analyser interfaced via a Conflo II to a Finnigan Mat Delta S isotope-ratio mass spectrometer, in turn interfaced with a Hewlett Packard 5890 GC. Denitrification rates were calculated according to the isotope pairing equations of Dalsgaard et al. (2000).

$\mathbf{N}_{2}$ fixation. $\mathrm{N}_{2}$ fixation was measured by the acetylene reduction assay (Capone 1993). Cores were raised until the tops were clear of the water surface and water was gently removed until a depth of 50 $\mathrm{mm}$ remained over the sediment-water interface and sufficient to cover the stirrer bars. The cores were capped, using airtight clear lids, and acetylene was injected via a small septum to give a concentration of $>20 \%$. For each incubation, a time series of 3 gas samples was collected via the septa into $5 \mathrm{ml}$ evacuated glass tubes (Vacutainer). Four hour incubations were performed, illuminated (500 $\mu$ moles of photons $\mathrm{m}^{-2} \mathrm{~s}^{-1}$ ) during the day and in the dark overnight, to capture any diurnal patterns of $\mathrm{N}_{2}$ fixation. Two cores were incubated for each depth and transect: 1 in the light, 1 in the dark. The concentration of ethylene in the gas samples was measured within $1 \mathrm{wk}$ using a Hewlett Packard 5890 GC equipped with an Alltech AT Alumina column ( $30 \mathrm{~m}, 0.53 \mathrm{~mm}$ i.d.) and a FID. A conversion factor of $4: 1$ was used to convert ethylene reduction to potential $\mathrm{N}_{2}$ fixation (Capone et al. 1992).

Statistics. We used analysis of variance (ANOVA) or the general linear model routine followed by Tukey's Honestly Significant Difference test (post hoc) in SPSS or Dunnett's test in Sigma Stat (Systat Software). Other statistical procedures included paired $t$-tests and Pearson's correlations. Where necessary, data were natural log transformed to stabilise variance.

\section{RESULTS}

\section{Site description}

The sand at $1.5 \mathrm{~m}$ had ripples $\sim 8 \mathrm{~cm}$ high with a spacing of $\sim 15 \mathrm{~cm}$, and was even-coloured pale grey. At the $4 \mathrm{~m}$ site, there were ripples $\sim 5 \mathrm{~cm}$ high, but none were seen at $8 \mathrm{~m}$. Patches of seagrass, mainly Halophila ovalis, were observed at the 4 and $8 \mathrm{~m}$ sites, but not at 1.5 or $14 \mathrm{~m}$. Sediments at both of the intermediate depths were unevenly coloured golden-brown; this colouring was commonly marked by broad (about $12-15 \mathrm{~cm}$ ) trails of pale-grey coloured sand which were made by numerous large sand dollars Peronella lesueuri, present at densities of up to 6 ind. $\mathrm{m}^{-2}$. Sand dollars burrowed down to $20 \mathrm{~mm}$ deep in sediments, and at 4 and $8 \mathrm{~m}$ deep sites on all 3 transects but not at any 1.5 or $14 \mathrm{~m}$ sites. At $14 \mathrm{~m}$ depth, the bottom appeared dark brown, and there was a layer of material on the surface that divers could easily resuspend by gentle water movement, without visibly disturbing the grey sediment beneath. There were a few scattered, partially decomposed blades of seagrass.

Irradiance (PAR) at the sea surface was $2366.5 \mu$ moles of photons $\mathrm{m}^{-2} \mathrm{~s}^{-1}$. Using the January average daytime PAR from nearby Hope Valley, of $1756 \mu$ moles of photons $\mathrm{m}^{-2} \mathrm{~s}^{-1}$ (Mountford \& Greico 2002), resulted in a conservative estimate of $165 \mu$ moles of photons $\mathrm{m}^{-2} \mathrm{~s}^{-1}$ PAR in the deepest (22.1 m, Australian Hydrographic Service 2001) part of the sound at midday. Using the value of PAR measured at the surface, $2300 \mu$ moles of photons $\mathrm{m}^{-2} \mathrm{~s}^{-1}$, the $0.1 \%$ isobath is at $63 \mathrm{~m}$, with PAR of $2.5 \mu$ moles of photons $\mathrm{m}^{-2} \mathrm{~s}^{-1}$.

Sediment grain size (median \pm SE) at $1.5 \mathrm{~m} \mathrm{(309 \pm}$ $12 \mu \mathrm{m}$, medium sand) was around double that at $14 \mathrm{~m}$ $(155 \pm 1.44 \mu \mathrm{m}$, fine sand); the 8 and $4 \mathrm{~m}$ sites were of intermediate grain size and not significantly different from each other (Fig. 2A). Sediments at $14 \mathrm{~m}$ were significantly $(p<0.05)$ less well sorted than those at 4 and $8 \mathrm{~m}$. The greatest degree of sediment sorting was at the intermediate depths (Fig. 2B), though not significantly more than at $1.5 \mathrm{~m}$. Observations and granulometry indicated that the sediments of Parmelia Bank can be divided into 3 zones: a zone of highest wave disturbance at around $1.5 \mathrm{~m}$; the 4 and $8 \mathrm{~m}$ sites which were virtually indistinguishable from each other in terms of particle size and sorting; and apparently more stable depositional flat at $14 \mathrm{~m}$.

\section{Organic carbon and nitrogen}

Concentrations of OC were greatest at $14 \mathrm{~m}$ (Fig. 3A), significantly greater than the other depths. Total nitrogen concentrations were also greatest at 


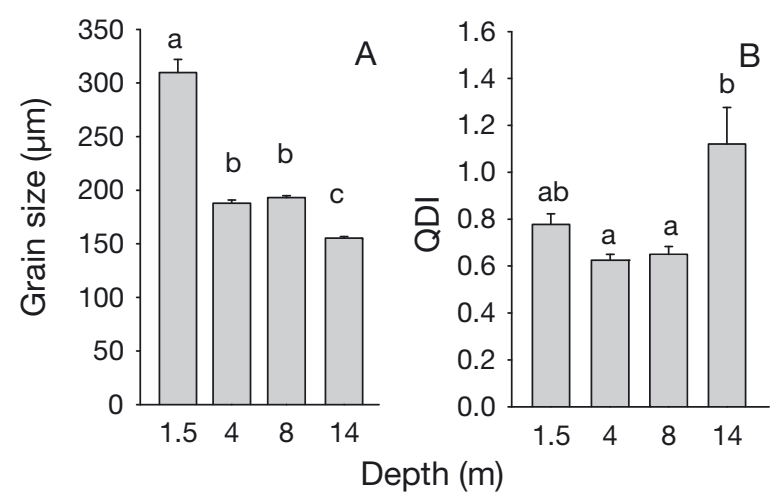

Fig. 2. Sediment granulometry at 1.5 to $14 \mathrm{~m}$ depths. (A) Median grain size and (B) inclusive graphic quartile deviation index (QDI) of sediment sorting. $\mathrm{n}=3$, error bars are $\mathrm{SE}$; different letters above bars denote significant difference by Tukey's HSD, $\alpha<0.05$

$14 \mathrm{~m}$ (Fig. 3B), and least at $1.5 \mathrm{~m}$; the 2 intermediate depths were intermediate and similar to each other. The C:N ratio was significantly greater at the $1.5 \mathrm{~m}$ sites than at the other depths (Fig. 3C). The ratio of OC to $\mathrm{chl}$ a was greater at the 14 and $1.5 \mathrm{~m}$ sites than at the intermediate depths (Fig. 3D).

\section{Pigments}

In this study, fucoxanthin was used as a diatom marker. Fucoxanthin is widely regarded as a marker pigment for diatoms, but it also occurs in prymnesiophytes, dinoflagellates and raphidophytes (Jeffrey et al. 1997). In our results, the absence of chl $c_{3}$ and peridinin make the first 2 classes unlikely sources. Raphidophytes could not be ruled out by pigment or lipid data, but the only reference that could be found to their occurrence in sediments was as resting stages (StahlDelbanco \& Hansson 2002). In the marine environment, chl $b$ is found in green algae, including prasinophytes, euglenophytes, chlorarachniophytes and chlorophytes. The sediments also contained the chlorophyte pigment lutein, and the correlation between lutein and chl $b$ was strong and consistent $(\mathrm{p}<0.001)$. The mean ratio of lutein:chl $b$ was 0.5 , similar to the ratio calculated for chlorophytes in water 0 to $25 \mathrm{~m}$ deep (Mackey et al. 1998). Hence in this study, chl $b$ was attributed to chlorophytes.

The $1.5 \mathrm{~m}$ sediments had significantly ( $\mathrm{p}<0.001)$ lower concentrations of chl a than the other depths: $42.3 \pm 1.83 \mathrm{mg} \mathrm{m}^{-2}$ ( $\mathrm{n}=12$; Fig. 4A). The greatest mean concentration was found at $4 \mathrm{~m}\left(89.13 \pm 6.05 \mathrm{mg} \mathrm{m}^{-2}\right)$. The ratio of phaeopigments (phaeophytin a plus pyrophaeophytin a) to chl $a$ at $1.5 \mathrm{~m}(0.008)$ was around an order of magnitude less than at the other depths (Fig. 4E).

The accessory pigments of the sediments were dominated $\left(95 \pm 1 \%\right.$ ) by chl $c_{1} \& C_{2}$, fucoxanthin, diadinoxanthin, diatoxanthin. The ratio of fucoxanthin:chl a was only significantly different to other depths at $1.5 \mathrm{~m}$ ( $p=0.005$; Fig. 4B). Cyanobacteria (zeaxanthin) were a minor component of the community at all depths (Fig. 4C). Using a zeaxanthin:chl a ratio of 0.59 (Gibb et al. 2001), cyanobacteria made contributions to biomass ranging from $3.6 \pm 0.1 \%$ of the chl $a$ at $1.5 \mathrm{~m}$ to $2.3 \pm 0.5 \%$ at $14 \mathrm{~m}$. The chlorophyte fraction of the BMA community increased with depth (Fig. 4D). Assuming a chl $b$ :chl a ratio of 0.57 (Gibb et al. 2001), chlorophytes comprised around $1 \%$ of chl a at $1.5 \mathrm{~m}$, but increased to $9.0 \pm 3 \%$ at $14 \mathrm{~m}$. The ratio of zeaxanthin:fucoxanthin was $12.9 \pm 0.6 \%$ at $1.5 \mathrm{~m}$, but only $3.1 \pm 0.9 \%$ at $4 \mathrm{~m}, 3.6 \pm 1.2 \%$ at $8 \mathrm{~m}$ and $4.6 \pm 0.4 \%$ at $14 \mathrm{~m}$.

\section{Lipids}

Phytol concentrations (Fig. 5A) at 4, 8 and $14 \mathrm{~m}$ were similar to each other, but concentrations were reduced by about $50 \%$ at $1.5 \mathrm{~m}$. The amount of total neutral lipids (Fig. 5B) was significantly reduced at $1.5 \mathrm{~m} \mathrm{(40 \pm}$ $\left.2 \mathrm{mg} \mathrm{m}^{-2}\right)$ relative to other depths $\left(F_{3,8}=41.5, \mathrm{p}<\right.$ $0.001)$ and was greatest at $14 \mathrm{~m}\left(134 \pm 5 \mathrm{mg} \mathrm{m}^{-2}\right)$. The stanol:stenol ratio (Fig. 5C) was also least at $1.5 \mathrm{~m}$ $\left(F_{3,8}=33.7, \mathrm{p}<0.001\right)$ and greatest at $14 \mathrm{~m}(0.19 \pm$ 0.01 ). The values of the ratio changed with depth in a similar way to the ratio of phaeopigments:chl a
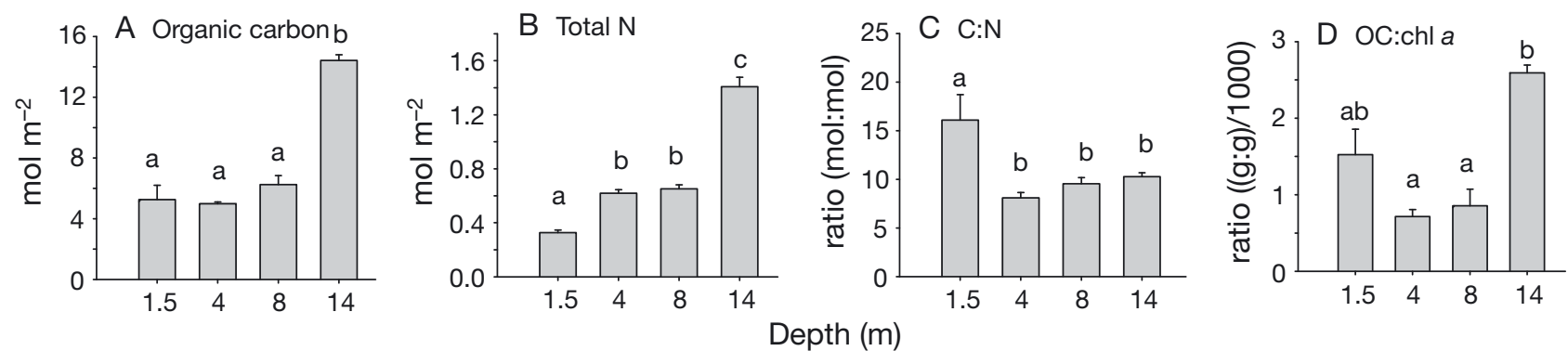

Fig. 3. Sediment concentration of (A) organic carbon (OC), (B) total nitrogen (N), (C) OC:total N molar ratio, (D) OC:chl a ratio by weight. $n=3$, error bars are $S E$; different letters above bars denote significant difference by Tukey's HSD, $\alpha<0.05$ 

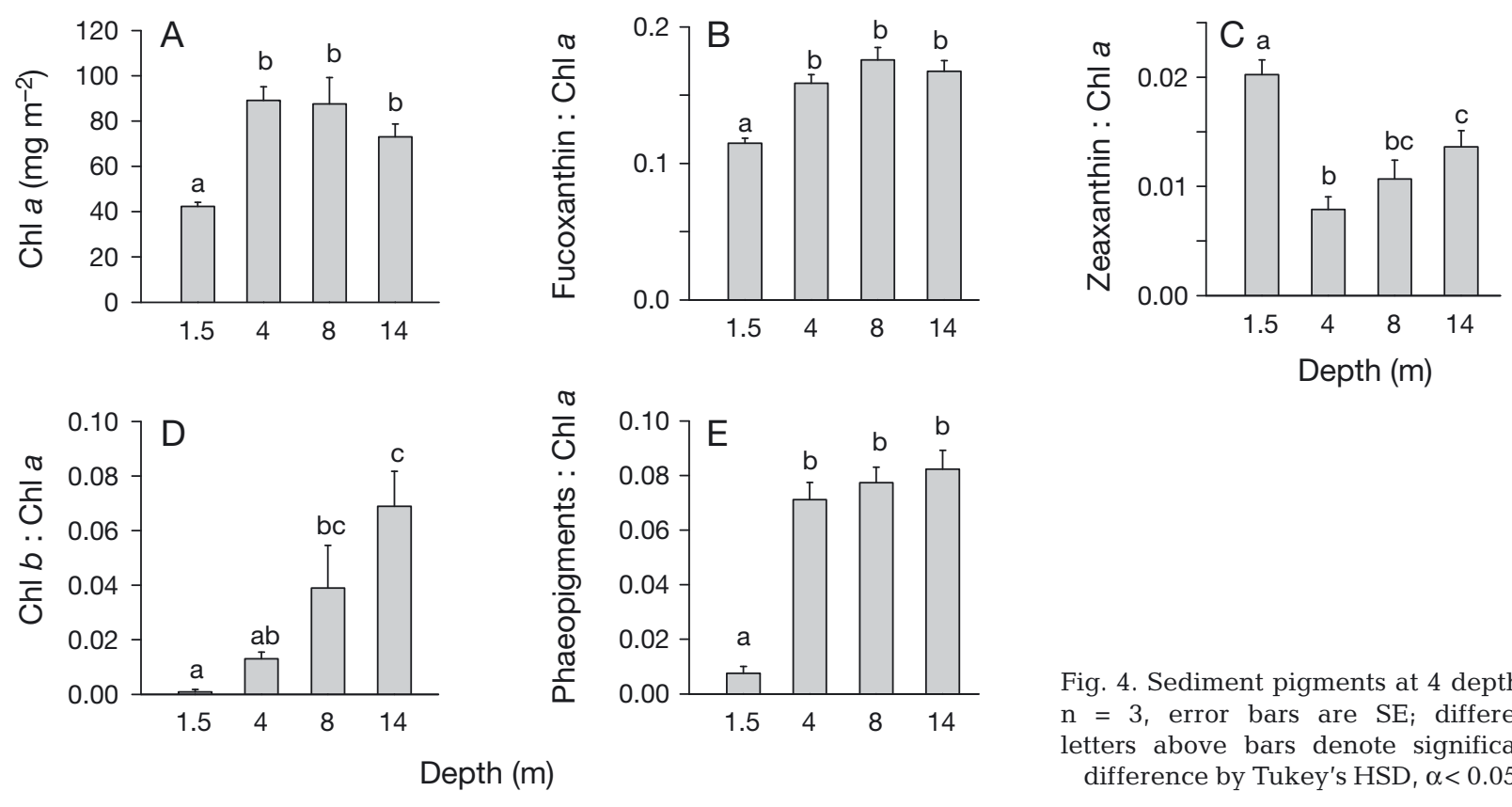

Fig. 4. Sediment pigments at 4 depths. $\mathrm{n}=3$, error bars are $\mathrm{SE}$; different letters above bars denote significant difference by Tukey's HSD, $\alpha<0.05$
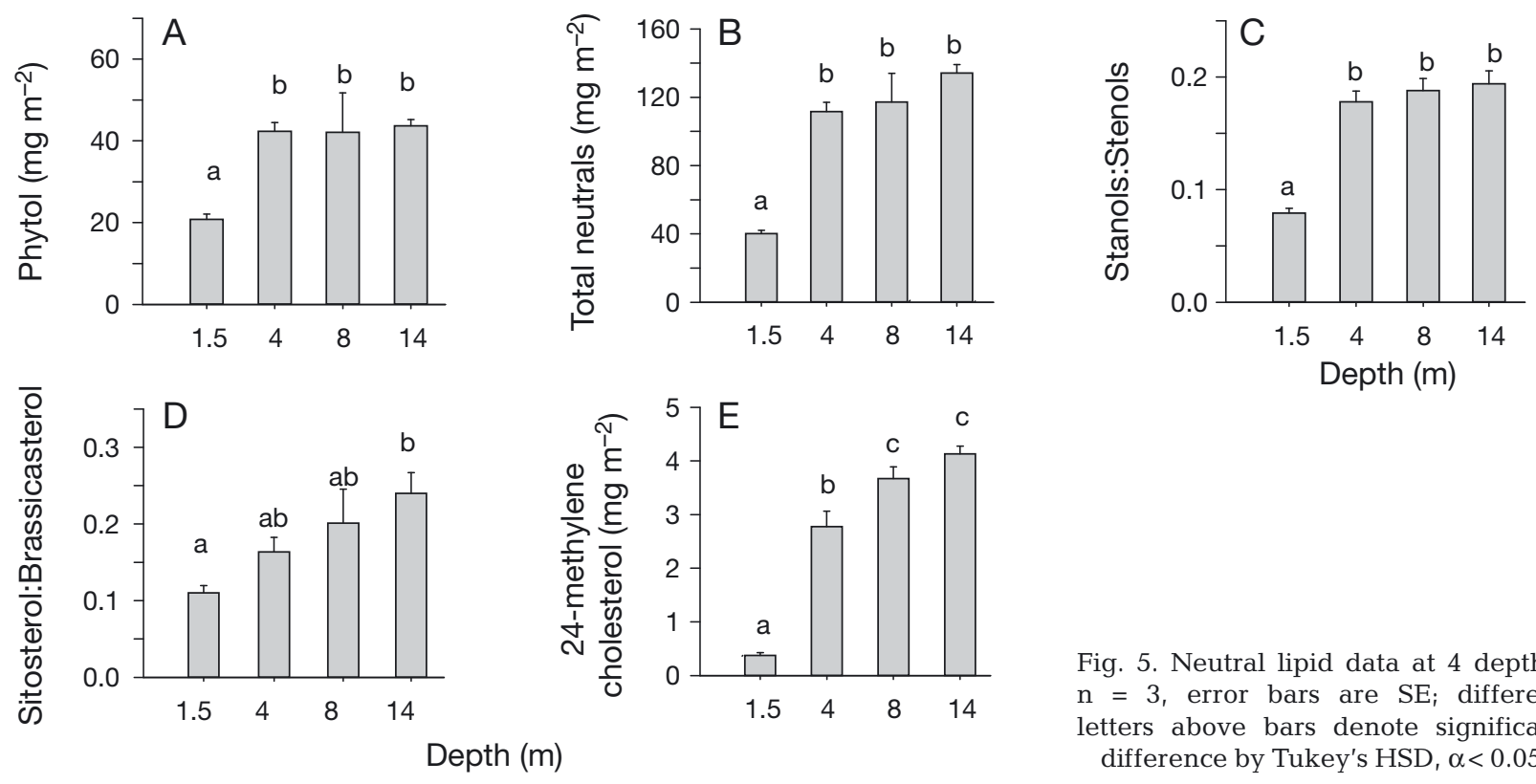

Fig. 5. Neutral lipid data at 4 depths. $\mathrm{n}=3$, error bars are $\mathrm{SE}_{\text {; }}$ different letters above bars denote significant difference by Tukey's HSD, $\alpha<0.05$

(Fig. 4E) (Pearson's $\mathrm{R}=0.934, \mathrm{p}<0.001$ ). The ratio of sitosterol to brassicasterol was less at $1.5 \mathrm{~m}$ than at $14 \mathrm{~m}\left(F_{3,8}=32.6, \mathrm{p}<0.001\right)$; the ratio was not significantly different between the other depths (Fig. 5D). At $1.5 \mathrm{~m}$, concentration of 24-methylene cholesterol, a sterol found particularly in centric diatoms, was $\sim 1 / 10$ of that found at the other depths (Fig. 5E), and increased at a reduced rate between 4 and $14 \mathrm{~m}$. The ratio of cholesterol (a sterol often used as a marker of grazers) to total sterols was not significantly different between depths $\left(F_{3,8}=2.48, \mathrm{p}=0.135\right)$.

BMA and bacterial FAs (for methods of allocation see Table S1) dominated the fatty acids in the sediments (Fig. 6A,B). Relationships between bacterial and algal markers were strong and significant, a correlation of the total bacterial FAs against algal FAs gave a Pearson's R of 0.917 ( $p<0.001$ ). Correlation between phytol and total glycerol ether diols (bacterial neutral lipids) 


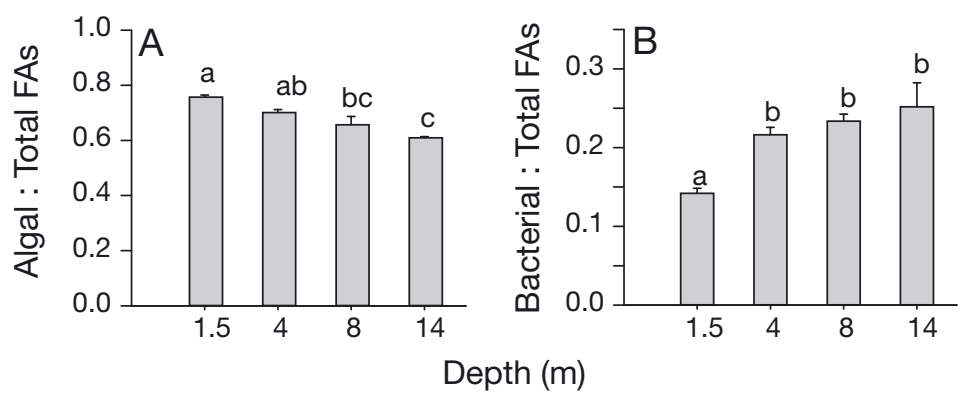

Fig. 6. Fatty acid (FA) data at 4 depths. $\mathrm{n}=3$, error bars are SE; different letters above bars denote significant difference by Tukey's HSD, $\alpha<0.05$

had an $\mathrm{R}$ value of 0.899 ( $\mathrm{p}<0.001)$. The ratio of algal: total FAs (linear regression: $\mathrm{R}=0.740, \mathrm{p}=0.006$ ) decreased with depth, while the ratio of bacterial:total FAs increased (linear regression: $\mathrm{R}=0.893, \mathrm{p}<0.001$; Fig. 6B). Though not significantly different from 8 or $14 \mathrm{~m}$, the greatest mean concentrations of algal (185 \pm $21 \mathrm{mg} \mathrm{m}^{-2}$ ) and bacterial (56 $\pm 3 \mathrm{mg} \mathrm{m}^{-2}$ ) FAs were found at $4 \mathrm{~m}$. The BMA fatty acids averaged $68 \pm 2 \%$ of total FAs across all depths.

The Halophila ovalis leaves contained the following concentrations of sterols ( $\mu \mathrm{g} \mathrm{g}^{-1}$ dry weight of leaf): cholesterol 1.17, campesterol 1.99, stigmasterol 1.89, sitosterol 12.11. The ratio of sitosterol to phytol in the leaves was 0.17, campesterol:phytol 0.03, and stigmasterol:phytol 0.03. In Parmelia Bank sediments, the nearest value of the sitosterol:phytol ratio was $0.16 \pm$ $0.02(\mathrm{n}=3)$ at $4 \mathrm{~m}$ depth, possibly due to the abundance of $H$. ovalis; the campesterol:phytol ratio was 0.09, and stigmasterol:phytol was 0.10.

\section{Oxygen fluxes}

Both NPP and CR were least at $1.5 \mathrm{~m}$ (Fig. 7A). Oxygen fluxes at the other depths were not significantly different from each other. The maximum value of NPP was $2.4 \pm 1.0 \mathrm{mmol} \mathrm{O} \mathrm{m}^{-2} \mathrm{~h}^{-1}(\mathrm{n}=6)$ measured at $4 \mathrm{~m}$; the greatest CR was $1.05 \pm 0.06$ mmol $\mathrm{O}_{2} \mathrm{~m}^{-2} \mathrm{~h}^{-1}(\mathrm{n}=6)$, measured at $14 \mathrm{~m}$. The productivity:respiration $(\mathrm{P}: \mathrm{R})$ ratio, calculated as GPP:CR, was $0.19 \pm 0.09$ at $1.5 \mathrm{~m}$, an order of magnitude less than at the other depths (Fig. 7B). Using an average of the ratio of NPP:ETR from the other depths (117.4 \pm 14.0), based upon measured rates of ETR at $1.5 \mathrm{~m}$ (see below), NPP at $1.5 \mathrm{~m}$ was 2.01 mmol $\mathrm{O}_{2} \mathrm{~m}^{-2} \mathrm{~h}^{-1}$. As the measured NPP was $0.02 \mathrm{mmol} \mathrm{m}^{-2} \mathrm{~h}^{-1}$, the oxygen uptake in the light was around $2 \mathrm{mmol} \mathrm{O}_{2} \mathrm{~m}^{-2} \mathrm{~h}^{-1}$, or more than double that in the dark $\left(0.716 \pm 0.099 \mathrm{mmol} \mathrm{O}_{2}\right.$ $\mathrm{m}^{-2} \mathrm{~h}^{-1}$ ). Estimated in situ NPP over a full day was not significantly different from 0 at $1.5 \mathrm{~m}$, rose sharply to $32 \pm 13 \mathrm{mmol} \mathrm{O}_{2} \mathrm{~m}^{-2} \mathrm{~d}^{-1}(\mathrm{n}=6)$ or $0.34 \pm 0.11 \mathrm{mmol} \mathrm{O}_{2}$ $\mathrm{mg} \operatorname{chl} \mathrm{a}^{-1}(\mathrm{n}=6)$ at $4 \mathrm{~m}$ and then decreased steadily (though not significantly) to $22 \pm 9 \mathrm{mmol} \mathrm{O}_{2} \mathrm{~m}^{-2} \mathrm{~d}^{-1}$ (n =6) or $0.28 \pm 0.07 \mathrm{mmol} \mathrm{O}_{2} \mathrm{mg} \mathrm{chl} \mathrm{a^{-1 }}(\mathrm{n}=6)$ at $14 \mathrm{~m}$ (Fig. 7C). Over the depths from 4 to $14 \mathrm{~m}$, the average rate of NPP was $26.5 \pm 4.2 \mathrm{mmol} \mathrm{O}_{2} \mathrm{~m}^{-2} \mathrm{~d}^{-1}$ or $0.30 \pm$ $0.02 \mathrm{mmol} \mathrm{O}_{2} \mathrm{mg} \mathrm{chl} \mathrm{a}^{-1}(\mathrm{n}=4)$, or $\sim 22 \mathrm{mmol} \mathrm{C} \mathrm{m}^{-2} \mathrm{~d}^{-1}$.

\section{Fluorometry}

As determined by fluorescence, the biomass of all BMA taxa was lowest at $1.5 \mathrm{~m}$ (Fig. 8A) and greatest at the intermediate depths. $\Delta F$, a high precision proxy for biomass, was up to an order of magnitude greater for diatoms than for cyanophytes and chlorophytes (Fig. 8A). The relative proportions of $\Delta F$ for diatoms and cyanophytes varied with depth, such that the ratio $\Delta F_{\mathrm{CY}}: \Delta F_{\mathrm{D}}$ was lower at $1.5 \mathrm{~m}$ than at the other depths, indicating the greatest dominance of diatom activity over cyanophytes at the shallowest sites. $\Delta F$ for chlorophytes was similar to that of cyanophytes, around 2 orders of magnitude less than for diatoms. Thus the
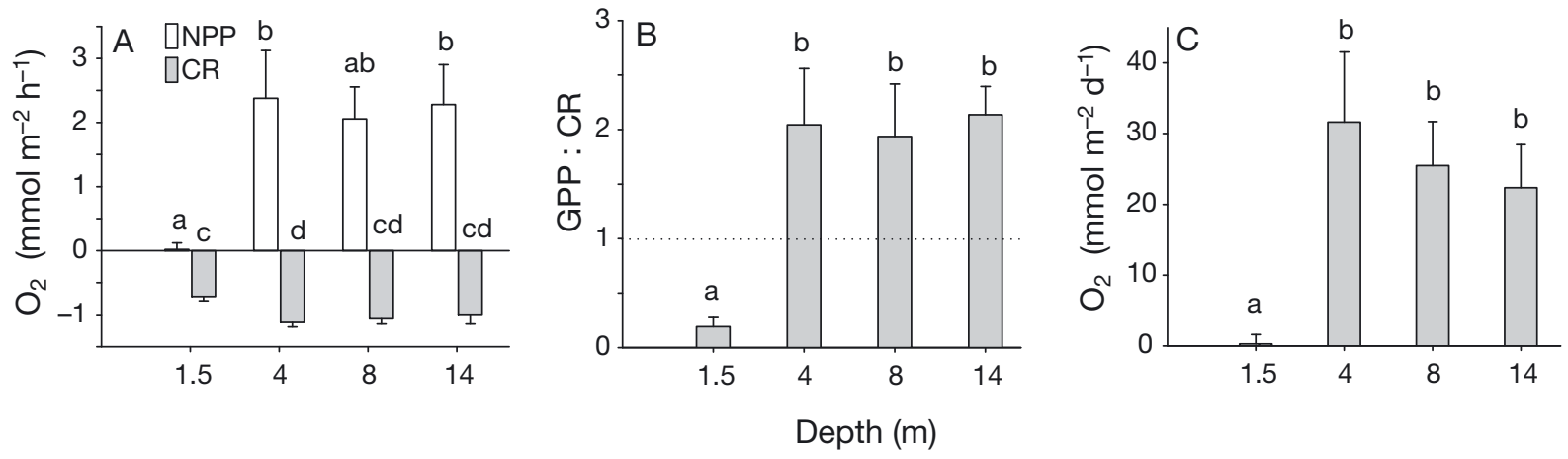

Fig. 7. Oxygen data at 4 depths. (A) net primary productivity (NPP) and community respiration (CR). (B) Gross primary productivity (GPP): CR, i.e. P:R ratio. (C) NPP over a full day (13.4 h of light), corrected for irradiance at different depths. Negative values denote flux into the sediment. $\mathrm{n}=6$, error bars are $\mathrm{SE}$; different letters above bars denote significant difference by Tukey's 
community composition determined by fluorescence was primarily browns, ranging from $90 \%$ at $1.5 \mathrm{~m}$ to $83 \%$ at $14 \mathrm{~m}_{\text {; }}$ contributions by cyanophytes and chlorophytes were around an order of magnitude less. Assuming the browns were largely diatoms, these results are consistent with those determined from other biomarkers.

Photosynthetic performance measured as the maximum electron transport rates $\left(\mathrm{ETR}_{\max }\right)$, the irradiance required to saturate ETR $\left(\mathrm{I}_{\text {opt }}\right)$ and the initial slope of the irradiance versus ETR curve ( $\alpha=$ alpha) varied significantly with depth $(\mathrm{p}=0.007,<0.001,<0.001$, respectively). The irradiance required to saturate electron transport $\left(\mathrm{I}_{\text {opt }}\right)$ was greatest at $1.5 \mathrm{~m}$ (Fig. 8B), and least at $14 \mathrm{~m}$. For example, $\mathrm{I}_{\text {opt }}$ for browns was $93 \mu$ moles of photons $\mathrm{m}^{-2} \mathrm{~s}^{-1}$ at $1.5 \mathrm{~m}$ and $63 \mu$ moles of photons $\mathrm{m}^{-2} \mathrm{~s}^{-1}$ at $14 \mathrm{~m}$. $\mathrm{I}_{\mathrm{opt}}$ was measurable for cyanophytes and browns at all depths and showed consistent and significant decreases with depth (Fig. 8B). The $\mathrm{I}_{\text {opt }}$ irradiance measured for cyanophytes at $14 \mathrm{~m}$ depth was $86.2 \mu \mathrm{mol}$ of photons $\mathrm{m}^{-2} \mathrm{~s}^{-1}$, which was greater than the optimal intensity for diatoms and chlorophytes at that depth (Fig. 8B). ETR max $_{\text {ax }}$ and $\alpha$ were least at $14 \mathrm{~m}$ and increased at 4 and $8 \mathrm{~m}$ before declining again at $1.5 \mathrm{~m}$ (Fig. $8 \mathrm{C}$ ). The effective quantum yield $\left(\theta_{\text {PSII }}\right)$ also varied significantly with depth $(\mathrm{p}<0.001)$
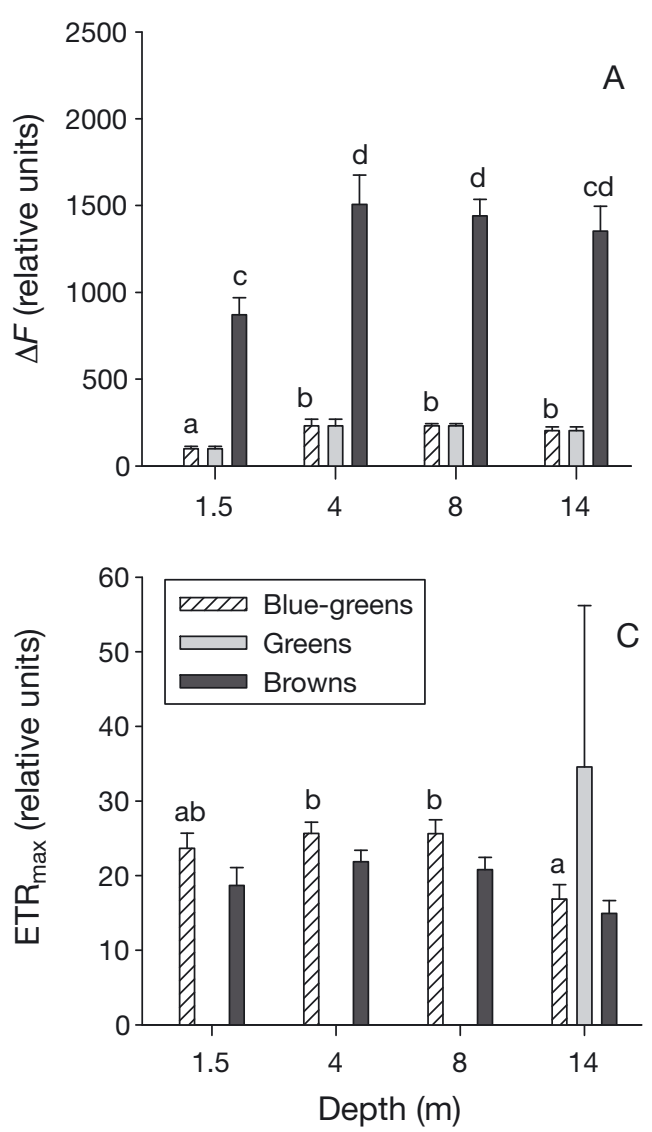

being as low as 0.43 at $1.5 \mathrm{~m}$ before rising to 0.60 at $8 \mathrm{~m}$ and then declining to 0.56 at $14 \mathrm{~m}$; this pattern was similar to $\mathrm{ETR}_{\max } \mathrm{I}_{\mathrm{opt}}$ and $\alpha$. There were no significant differences in $\theta_{\text {PSII }}$ between taxa.

\section{Nutrient fluxes}

Fluxes of inorganic nutrients were, generally, highly variable between replicates at each depth (Fig. 9A-D). As a general result, the flux rates of inorganic nutrients were not significantly influenced by depth or irradiance. When net $(24 \mathrm{~h})$ fluxes were averaged over the 4 depths, $\mathrm{NH}_{4}$ was the dominant inorganic nutrient (efflux of $170 \pm 326 \mu \mathrm{mol} \mathrm{m}^{-2} \mathrm{~d}^{-1}$ ). There was uptake of Si $\left(74 \pm 79 \mu \mathrm{mol} \mathrm{m}{ }^{-2} \mathrm{~d}^{-1}\right)$ and efflux of $\mathrm{PO}_{4}(14 \pm$ $\left.27 \mu \mathrm{mol} \mathrm{m}{ }^{-2} \mathrm{~d}^{-1}\right) ; \mathrm{NO}_{\mathrm{x}}$ efflux was just $2 \pm 4 \mu \mathrm{mol} \mathrm{m}{ }^{-2}$ $\mathrm{d}^{-1}$. The N:P ratio of the sediment to water column exchange of dissolved inorganic nutrients averaged over 1.5 to $14 \mathrm{~m}$ was 13 .

The $1.5 \mathrm{~m}$ sediments were the exception, as there was efflux of $\mathrm{Si}_{1} \mathrm{PO}_{4}$ and $\mathrm{NH}_{4}$ in the light and uptake in the dark, with the differences being significant $(\mathrm{p}$ $<0.01$ ). $\mathrm{NO}_{\mathrm{x}}$ fluxes at $1.5 \mathrm{~m}$ were out of the sediment both in the light and in the dark, but were 2 orders of magnitude smaller than $\mathrm{NH}_{4}$ fluxes; net fluxes over

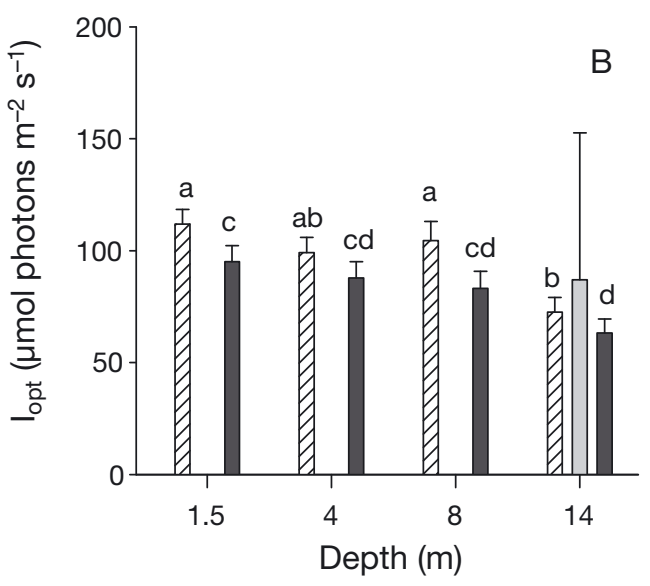

Fig. 8. Fluorescence parameters of benthic microalgal communities measured in intact cores from 4 depths $(\mathrm{n}=18)$. (A) Active fluorescence $(\Delta F)$, the difference between the fluorescence yield from a repeated saturating pulse (maximum yield, $F_{\mathrm{m}}$ ) and the yield in the near dark $\left(F_{\mathrm{o}}\right)$ after Brack \& Frank (1998) and provides a precise measure of relative biomass in the 3 different taxa. (B) $\mathrm{I}_{\mathrm{opt}}$, the irradiance that saturates electron transport rates (ETR). (C) The photosynthetic parameter $\mathrm{ETR}_{\max }$ (maximum ETR). Error bars are SE; different letters above bars denote significant difference by Tukey's HSD, $\alpha<0.05$. See Materials and Methods for details of the calculations 
$24 \mathrm{~h}$ were near 0 for $\mathrm{Si}_{1} \mathrm{PO}_{4}$ and $\mathrm{NH}_{4}$. At $4 \mathrm{~m}$ there was uptake of $\mathrm{Si}\left(11.3 \pm 3.5 \mu \mathrm{mol} \mathrm{m}{ }^{-2} \mathrm{~h}^{-1}\right)$ and $\mathrm{NH}_{4}$ $\left(19 \pm 15 \mu \mathrm{mol} \mathrm{m}^{-2} \mathrm{~h}^{-1}\right)$ in the light, but effluxes of $\mathrm{PO}_{4}$ and $\mathrm{NO}_{\mathrm{x}}$ i there were no significant differences between fluxes in illuminated and dark incubations. At $8 \mathrm{~m}$, there was large variability in fluxes; Si fluxes were near $0, \mathrm{PO}_{4}$ and $\mathrm{NO}_{\mathrm{x}}$ were taken up in the dark and released in the light, and $\mathrm{NH}_{4}$ was released in both the light and dark. At $14 \mathrm{~m}$, fluxes of DIN were near $0, \mathrm{Si}$ was taken up in the light and released in the dark and $\mathrm{PO}_{4}$ was released in the light and taken up in the dark. Over $24 \mathrm{~h}$, fluxes of inorganic nutrients (Fig. 9E-H) were dominated by $\mathrm{NH}_{4}$ the greatest fluxes occurred at $4 \mathrm{~m}$ (uptake of $539 \pm 207 \mu \mathrm{mol}$ $\mathrm{m}^{-2} \mathrm{~d}^{-1}$ ) and $8 \mathrm{~m}$ (efflux of $1040 \pm 750 \mu \mathrm{mol} \mathrm{m}^{-2} \mathrm{~d}^{-1}$ ) depths. Atomic ratios of the inorganic nutrient fluxes rarely neared Redfield values (Redfield 1958). The closest approximations were an N:Si ratio (Redfield = 1:1) of 1.6:1 in illuminated sediments from $4 \mathrm{~m}, \mathrm{~N}: \mathrm{P}$ (Redfield $=16: 1$ ) of 24.3 in illuminated sediments from $8 \mathrm{~m}$ and $\mathrm{N}: \mathrm{Si}$ of 1.9:1 in darkened sediments from $1.5 \mathrm{~m}$.

\section{Denitrification}

Measurable denitrification only occurred in darkened cores at depths of 8 and $14 \mathrm{~m}$. Rates were around 2 orders of magnitude smaller than those of dissolved inorganic nitrogen (DIN). $\mathrm{N}_{2}$ effluxes were $0.08 \pm$ $0.04 \mu \mathrm{mol} \mathrm{m}^{-2} \mathrm{~h}^{-1}$ at $8 \mathrm{~m}$ and $0.09 \pm 0.03 \mu \mathrm{mol} \mathrm{m}^{-2} \mathrm{~h}^{-1}$ at $14 \mathrm{~m}$ depth. No denitrification was detected in any of the illuminated cores, or in samples from 1.5 or $4 \mathrm{~m}$ depths.
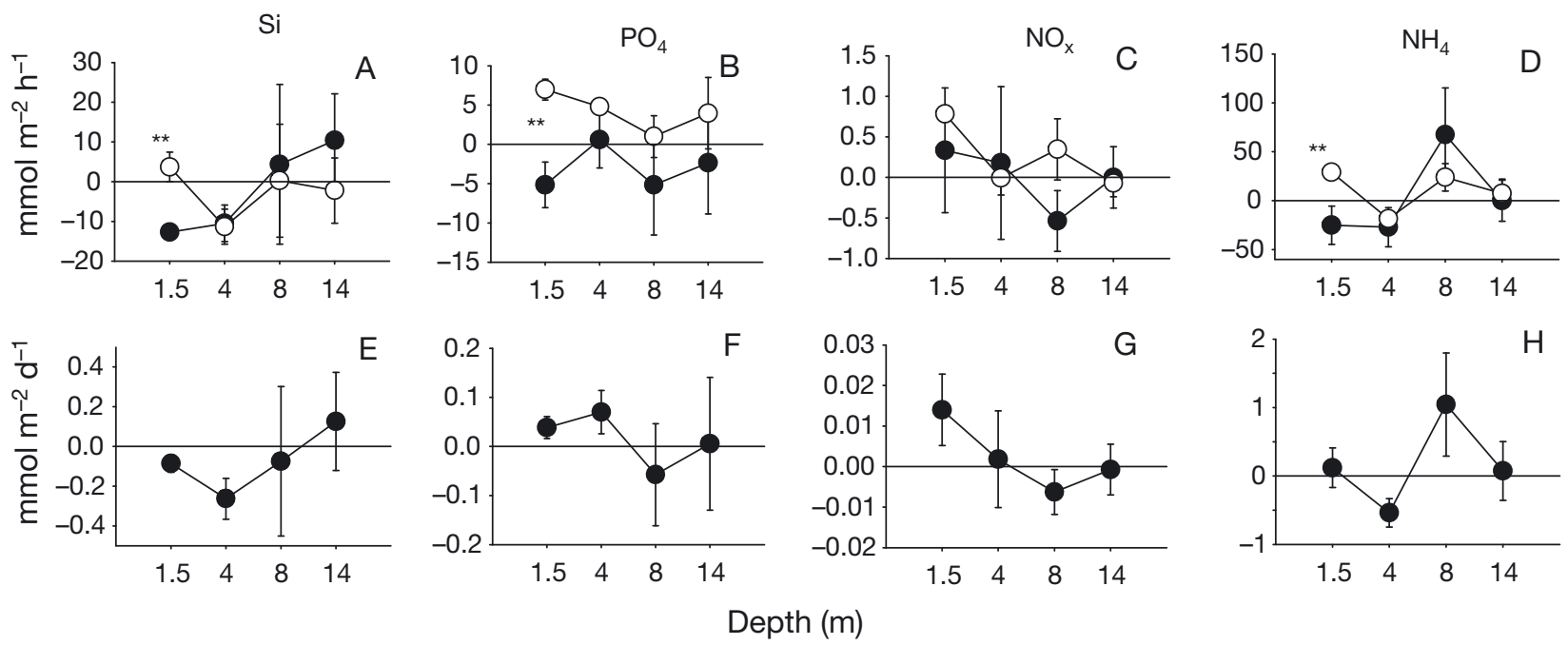

$\mathrm{N}_{2}$ fixation only occurred at 4 of the 12 sites, rates were less than the other DIN fluxes by around 2 orders of magnitude, but of a similar size to denitrification. In darkened cores, fixation was measured at 1 of the three $14 \mathrm{~m}$ sites (transect c: $0.13 \pm 0.01 \mu \mathrm{mol}$ ethylene $\mathrm{m}^{-2} \mathrm{~h}^{-1}$ ) and at 1 of the $4 \mathrm{~m}$ sites (transect a: $0.29 \pm$ $0.01 \mu \mathrm{mol}$ ethylene $\mathrm{m}^{-2} \mathrm{~h}^{-1}$ ). In illuminated cores, fixation was measured at two $14 \mathrm{~m}$ sites (transect a: $0.11 \pm$ $0.01 \mu \mathrm{mol}$ ethylene $\mathrm{m}^{-2} \mathrm{~h}^{-1}$ and transect c: $0.29 \pm$ $0.01 \mu \mathrm{mol}$ ethylene $\mathrm{m}^{-2} \mathrm{~h}^{-1}$ ). The greatest of these rates (0.29) only equates to $0.07 \mu \mathrm{mol} \mathrm{N}_{2} \mathrm{~m}^{-2} \mathrm{~h}^{-1}$ (using a ratio of 4 moles of acetylene reduced per mole of $\mathrm{N}_{2}$ fixed; see Materials and Methods).

\section{Summary of results}

The sampled depths could be divided into 3 zones by physical parameters and 2 by biological parameters. The $1.5 \mathrm{~m}$ sites had wave-washed, coarse sediments with lowest BMA biomass, high OC content and a dominantly heterotrophic metabolism. The middle zone, comprising the 4 and $8 \mathrm{~m}$ sites, was heavily grazed and disturbed by sand dollars. The granulometry of the 2 intermediate sites was nearly indistinguishable. The $14 \mathrm{~m}$ sites were in a flat, depositional zone, with the smallest grain size and least-sorted sediments. The deepest sites had the highest biomass by concentrations of OC, total $\mathrm{N}$ and sterols. The $14 \mathrm{~m}$ sediments also had the highest ratio of bacterial to BMA FAs. Fluxes of inorganic nutrients were dominated by $\mathrm{NH}_{4}$, net $24 \mathrm{~h}$ rates were near 0 at 1.5 and $14 \mathrm{~m}$ depths, but there was uptake at $4 \mathrm{~m}$ and efflux at $8 \mathrm{~m}$.

Fig. 9. Inorganic nutrient fluxes at 4 depths. (A-D) Hourly rates in illuminated (O) and darkened (O) incubations. (E-H) $24 \mathrm{~h}$ rates corrected for in situ photoperiods at different depths. Negative values denote flux into the sediment $(\mathrm{n}=6$, error bars are SE, ${ }^{* *}$ indicates significant difference between light and dark fluxes, $\mathrm{p}<0.01$ ) 


\section{DISCUSSION}

The dominance of the BMA community by diatoms was apparent from both pigment and lipid markers. Diatoms are the dominant taxon of BMA in many parts of the world (Cahoon 1999). Nutrient competition experiments carried out on mixed benthic communities (Sommer 1996) showed that diatoms out-competed cyanophytes and chlorophytes over a range of $\mathrm{N}: \mathrm{P}$ ratios as long as $\mathrm{Si}$ was not limiting. The consistent dominance by diatoms of the BMA community on Parmelia Bank suggests that Si was not limiting at any depth, and the greater uptake of $\mathrm{Si}$ at $4 \mathrm{~m}$ suggests strong diatom growth at that depth. The correlation between lutein and chl $b$ suggests the presence of chlorophytes (Brotas \& Plante-Cuny 2003) ranging from $1 \%$ of BMA at $1.5 \mathrm{~m}$ to $9 \%$ at $14 \mathrm{~m}$. Concentrations of the cyanophyte accessory pigment zeaxanthin were low, suggesting the BMA were 3.6\% cyanophytes. The fluorescence-based estimate of cyanophyte biomass was of up to $17 \%$ of BMA, possibly greater because of differences in the pigment ratios between the species used to calibrate the fluorometer and those in growing in the sediments, or measurement of cyclic electron flow around Photosystem I (Falkowski \& Raven 2007). The low biomass of cyanophytes and absence of $\mathrm{N}_{2}$ fixation implies that concentrations of DIN remained adequate for diatom requirements even throughout summer.

The BMA chl a biomass data from 17 temperate sites over the depth range of 5 to $20 \mathrm{~m}$ averaged $84 \pm 204 \mathrm{mg}$ $\mathrm{m}^{-2}$ (Cahoon 1999), which is very similar to the 75 to $89 \mathrm{mg} \mathrm{m}^{-2}$ found in these moderately exposed sediments from the southwest coast of Australia over the depth range of 4 to $14 \mathrm{~m}$. The results from $1.5 \mathrm{~m}$ depth contrast sharply with this general accord with international observations; chl a was $42 \mathrm{mg} \mathrm{m}^{-2}$, or only $30 \%$ of the average $128 \mathrm{mg} \mathrm{m}^{-2}$ reported by Cahoon (1999) at similar depths in 16 temperate zone locations. On the local scale, the BMA biomass in terms of lipids, chl a (measured by fluorescence and HPLC), and total $\mathrm{N}$ was $50 \%$ less at $1.5 \mathrm{~m}$ than that at other depths.

A range of mechanisms might explain the pronounced decline in BMA in shallow waters. Of these, we suggest that grazing played a relatively minor role, since the phaeopigment:chl a ratio was lowest at $1.5 \mathrm{~m}$. In addition, the concentration of cholesterol, a sterol marker of eukaryotic heterotrophs and grazing, was not significantly different between $1.5 \mathrm{~m}$ and the other depths. It is well known that there is an inverse relationship between grain size and biomass of benthic diatoms (Cahoon et al. 1999, Watermann et al. 1999). The primary factor determining sediment grain size is the degree of physical disturbance (de Jong \& de Jonge 1995). The grain size of the sediments at $1.5 \mathrm{~m}$ on Parmelia Bank was significantly greater than at the other depths. Therefore, the abrupt reduction in biomass represents a decrease in BMA retention because of the more frequent, wave-driven resuspension of the shallow sediments (Barranguet et al. 1998). The contrast between the disturbed $1.5 \mathrm{~m}$ sites and more protected $4 \mathrm{~m}$ sites was similar to the negative relationship between wave disturbance and BMA biomass in southwestern Sweden (Sundbäck 1984), the Westerschelde Estuary in The Netherlands (Barranguet et al. 1998) and the Huon Estuary, Australia (Cook et al. 2004a). We suggest that much of the $250 \%$ site variation reported by Cahoon (1999) is due to variation in physical dispersion.

Despite the $1.5 \mathrm{~m}$ sediments having the smallest biomass, as measured by chl a, phytol and total neutral lipids, the OC concentration of the sediment was similar to that at the 4 and $8 \mathrm{~m}$ sites. The biomarker data did not suggest that there had been an accumulation of OM with an elevated C:N ratio (such as seagrass debris). The concentration of the major sterol of Halophila ovalis, sitosterol, and its ratio to the diatom sterol brassicasterol, was the lowest at $1.5 \mathrm{~m}$. The C:N ratio at $1.5 \mathrm{~m}(16.1 \pm 2.6, \mathrm{n}=6)$ was nearly double that of the other depths, and well above the Redfield value of 6.6 (Redfield 1958). The ratio of BMA to total FA was greatest in $1.5 \mathrm{~m}$ sediments. A potential cause of elevated $\mathrm{C}: \mathrm{N}$ ratios, particularly in shallow sediments, is the presence of carbohydrates secreted by BMA (Decho 1990). The small effluxes of inorganic nutrients from the $1.5 \mathrm{~m}$ sediments suggests that porewater concentrations were relatively low, consistent with more wave flushing of these coarser sediments (Janssen et al. 2005). Environmental conditions of high irradiance and low nutrient availability promote the production of carbohydrates by BMA (Staats et al. 2000). Combined with a larger proportion of attached (epipsammic) diatoms that cannot migrate away from excess light (Admiraal 1984, Barranguet et al. 1997), the rates of photosynthesis at $1.5 \mathrm{~m}$ were likely to periodically exceed those required for balanced growth. Hence in the shallow sediments at $1.5 \mathrm{~m}$, washed by oligotrophic waters and subject to high levels of PAR, secretions of carbohydrates by BMA are a likely cause of the elevated $\mathrm{C}: \mathrm{N}$ ratio.

Bacteria comprised the smallest fraction of the sediment community at $1.5 \mathrm{~m}$, presumably in response to the more energetic hydrodynamic conditions. In a flume experiment that gradually increased current speed over sediments, heterotrophic bacteria were resuspended before BMA (Shimeta et al. 2002). In spite of the low bacterial biomass at $1.5 \mathrm{~m}$, the BMA biomass was $42 \mathrm{mg} \mathrm{m}^{-2}$ and $\mathrm{ETR}_{\mathrm{MAX}}$ was similar to other depths, yet the rate of GPP was negligible, suggesting a very high rate of oxygen consumption in illuminated 
sediments. Generally, ETR is proportional to the photosynthetic rate, although it can underestimate $\mathrm{C}$ fixation in strong PAR conditions (Carr \& Bjork 2003). Only at $1.5 \mathrm{~m}$ were the sediments net heterotrophic and the $\mathrm{P}: \mathrm{R}$ ratio was an order of magnitude less than the other depths. The efflux of inorganic nutrients in the light was consistently and significantly greater than in the dark, suggesting that bacterial rates of OM breakdown exceeded the capacity of BMA for assimilation. The dark uptake of Si by diatoms at $1.5 \mathrm{~m}(12.7 \pm 0.8 \mu \mathrm{mol}$ $\mathrm{m}^{-2} \mathrm{~h}^{-1}$ ) suggests that diatoms were responsible for $>10 \%$ of total benthic respiration, or $84 \mu \mathrm{mol} \mathrm{O}_{2} \mathrm{~m}^{-2}$ $\mathrm{h}^{-1}$ (using the Redfield ratio of $\mathrm{Si}$ C of 1:6.6, respiratory quotient of 1). Respiration dominated oxygen exchanges at $1.5 \mathrm{~m}$ and signs of bacterial activity were greatest there, yet the ratio used to infer rates of degradation of BMA (phaeopigments:chl a) was lowest by nearly an order of magnitude, and the more general index of diagenesis (stanol:sterol ratio) was reduced by half. The lipid ratio also implied that the degradation of BMA biomass by bacteria was significantly less important at $1.5 \mathrm{~m}$ than in the deeper, more sheltered sediments. We therefore suggest that much of the respiration in the $1.5 \mathrm{~m}$ sediments was due to consumption of the carbohydrates secreted by BMA. The carbohydrates secreted by BMA are known to stimulate bacterial growth (Murray et al. 1986) and are a substrate for microheterotrophs (Goto et al. 2001). These results suggest that the BMA drove the metabolism of these shallow, wave-disturbed sediments by secreting large

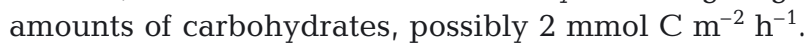
This rate was similar to those found in a study of shallow $(0.5-2.0 \mathrm{~m})$ subtidal sediments off the coast of Germany (Böer et al. 2008).

The sediments were strongly autotrophic at $14 \mathrm{~m}$, and GPP was not significantly correlated with depth, making it difficult to estimate at which depth the sediments became net heterotrophic $(\mathrm{GPP}=0)$. At this latitude, on the west coast of Australia, light attenuation $(k)$ varies with depth from $0.14 \mathrm{~m}^{-1}$ at $25 \mathrm{~m}$ to $0.07 \mathrm{~m}^{-1}$ at $100 \mathrm{~m}$ (P. Thompson unpublished) falling to $0.04 \mathrm{~m}^{-1}$ farther offshore (Thompson et al. 2007). Using the value of PAR measured at the surface, 2300 umoles of photons $\mathrm{m}^{-2} \mathrm{~s}^{-1}$, and a $k$ value of $0.1 \mathrm{~m}^{-1}$, the $0.1 \%$ isobath (PAR of $2.3 \mu$ moles of photons $\mathrm{m}^{-2} \mathrm{~s}^{-1}$ ) is at $63 \mathrm{~m}$, similar to the $60 \mathrm{~m}$ estimated by Cahoon (1999). At $63 \mathrm{~m}$, the photic zone extends to more than $50 \mathrm{~km}$ off shore along much of the west coast of Australia.

Grain size, sorting, BMA biomass, the exchanges of gases and inorganic nutrients at $14 \mathrm{~m}$ were similar to those at 4 and $8 \mathrm{~m}$. The relatively flat area at $14 \mathrm{~m}$ was an area of deposition and accumulation, presumably due to the reduced hydrodynamic energy. It had the greatest concentrations of total neutral lipids and concentrations of $\mathrm{OC}$ and total $\mathrm{N}$ around double that at the other depths. The C:chl a ratio was greater than at any other depth, more than double that at 4 or $8 \mathrm{~m}$. There were elevated concentrations of sitosterol, the major sterol ( $70 \%$ of total sterols) of the seagrass Halophila ovalis, suggesting that tissue from higher up on Parmelia Bank had contributed to the sediment OM. OM from seagrasses is refractory to degradation compared to microalgae, and can form a fraction of sediment OC that turns over slowly, or is buried (Jaffe et al. 2001), while chl a persists for less than $1 \mathrm{~d}$ in non-living matter (Sun et al. 1993). Concentrations of settled phytoplankton (24-methylene cholesterol) also increased with depth; a similar result was reported in a Swedish study (Wulff et al. 2005).

The macrofaunal grazer Peronella lesueuri (sand dollar) was only observed at intermediate depths, a habitat preference that may relate to the grain size (Pomory et al. 1995). Based on the concentrations of bacterial FA, cholesterol and ratios of degradation products, however, grazing was similar at 4, 8 and $14 \mathrm{~m}$ sites. The apparent absence of sand dollars from these deeper sediments suggests that microheterotrophs or small invertebrates were responsible for the relatively high levels of degradation products and cholesterol (associated with grazing and heterotrophs). This is similar to the Westerschelde Estuary (Barranguet et al. 1998), where relatively sheltered sediments had greater ratios of degradation products than more disturbed sandy sediments.

There were a number of changes in the sediment community with depth, but fewer changes in the resultant metabolism and biogeochemistry. The major shift occurred with a decrease in wave disturbance between 1.5 and $4 \mathrm{~m}$, where high levels of bacterial activity gave way to an autotrophic dominance. During this study in January (mid-summer) 2004, the major inorganic nutrient flux was $\mathrm{NH}_{4}$. Half of the net $(24 \mathrm{~h})$ inorganic nutrient fluxes measured (4 nutrients $\times 4$ depths) were not significantly different from 0 , suggesting an efficient recycling of OM between heterotrophs and autotrophs. When averaged over depth and $24 \mathrm{~h}$, the sediments were a net source of DIN and DIP, and a sink for Si. The averaged release of DIN into the water column was $170 \mu \mathrm{mol} \mathrm{m} \mathrm{m}^{-2} \mathrm{~d}^{-1}$, a contribution of $0.02 \mu \mathrm{mol} \mathrm{l}^{-1}$ in a $7 \mathrm{~m}$ deep water column. The absence of denitrification in the illuminated cores and the generally small rates were consistent with other studies reporting that photosynthesis inhibits denitrification in autotrophic sediments in oligotrophic waters (Rysgaard et al. 1995, Sundbäck et al. 2004). The small role played by $\mathrm{N}_{2}$ fixation further implies that $\mathrm{N}$ was not a limiting nutrient in these sediments. The magnitudes of the fluxes of denitrification and of $\mathrm{N}_{2}$ fixation suggest that these 2 fluxes may approximately balance in this environment. 


\section{SUMMARY}

BMA biomass was dominated by diatoms. In contrast to other studies, BMA biomass did not correlate with irradiance or depth, probably because of the relatively narrow range of depths (1.5 to $14 \mathrm{~m}$ ) investigated. Physical disturbance by waves in this exposed environment may also contribute to the relatively homogenous distribution of BMA biomass. The shallow site $(1.5 \mathrm{~m})$ had the lowest BMA biomass, presumably due to the highest rate of wave-induced physical disturbance. Sediments from 4 to $14 \mathrm{~m}$ were net autotrophic. With the exception of $1.5 \mathrm{~m}$, the flux rates of inorganic nutrients were not markedly influenced by depth or irradiance. Net $\mathrm{NH}_{4}$ and $\mathrm{PO}_{4}$ fluxes, albeit relatively small, were from the sediments into the water column at a molar N:P ratio of 13 , suggesting efficient recycling of OM across a range of conditions.

Acknowledgements. H.F. thanks G. Kendrick and A. Waite for helpful advice, field support and laboratory resources. Thanks to L. Clementson, A. Revill and J. Volkman for useful discussions; to S. Grove, A. Brearley and K. Kilminster for assistance with field work; P. Bonham for pigment analyses and chromatography; and 4 anonymous reviewers for their constructive suggestions. We acknowledge financial support of a PhD scholarship for H.F. and research funding from the Strategic Research Fund for the Marine Environment (a joint initiative of the Western Australian state government and Commonwealth Scientific and Industrial Research Organisation - Division of Marine and Atmospheric Research).

\section{LITERATURE CITED}

Admiraal W (1984) The ecology of estuarine sedimentinhabiting diatoms. In: Round FE, Chapman DJ (eds) Progress in phycological research, Vol 3. Biopress, Bristol, p 269-322

Australian Hydrographic Service (2001) Gage Roads and Cockburn Sound hydrographic charts. Australian Hydrographic Service, Wollongong

Baillie PW, Welsh BL (1980) The effect of tidal resuspension on the distribution of intertidal epipelic algae in an estuary. Estuar Coast Mar Sci 10:165-180

Barranguet C, Herman PMJ, Sinke JJ (1997) Microphytobenthos biomass and community composition studied by pigment biomarkers: importance and fate in the carbon cycle of a tidal flat. J Sea Res 38:59-70

Barranguet C, Kromkamp J, Peene J (1998) Factors controlling primary production and photosynthetic characteristics of intertidal microphytobenthos. Mar Ecol Prog Ser 173:117-126

Bidigare RR, Frank TJ, Zastrow C, Brooks JM (1986) The distribution of algal chlorophylls and their degradation products in the Southern Ocean. Deep-Sea Res 33:923-937

Blanchard GF, Montagna PA (1992) Photosynthetic response of natural assemblages of marine benthic microalgae to short-term and long-term variations of incident irradiance in Baffin Bay, Texas. J Phycol 28:7-14

Blanchard GF, Guarini JM, Orvain F, Sauriau PG (2001) Dynamic behaviour of benthic microalgal biomass in intertidal mudflats. J Exp Mar Biol Ecol 264:85-100
> Bligh EG, Dyer WJ (1959) A rapid method of total lipid extraction and purification. Can J Biochem Physiol 37:911-917

Böer SI, Arnosti C, Van Beusekom JEE, Boetius A (2008) Temporal variations in microbial activities and carbon turnover in subtidal sandy sediments. Biogeosci Discuss 5:4271-4313

Brachmanis J (2002) A regional review of coastal hazards along the southwest coast of Western Australia. Geoscience Australia, Perth

Brack W, Frank H (1998) Chlorophyll a fluorescence: a tool for the investigation of toxic effects in the photosynthetic apparatus. Ecotoxicol Environ Saf 40:34-41

> Brotas V, Plante-Cuny MR (2003) The use of HPLC pigment analysis to study microphytobenthos communities. Acta Oecol 24:S109-S115

Büchel C, Wilhelm C (1993) In vivo analysis of slow chlorophyll fluorescence induction kinetics in algae: progress, problems and perspectives. Photochem Photobiol 58: $137-148$

Cahoon LB (1999) The role of benthic microalgae in neritic ecosystems. Oceanogr Mar Biol Annu Rev 37:47-86

> Cahoon LB, Cooke JE (1992) Benthic microalgal production in Onslow Bay, North Carolina, USA. Mar Ecol Prog Ser 84:185-196

Cahoon LB, Beretich GR, Thomas CJ, McDonald AM (1993) Benthic microalgal production at Stellwagen Bank, Massachusetts Bay, USA. Mar Ecol Prog Ser 102:179-185

Cahoon LB, Laws RA, Thomas CJ (1994) Viable diatoms and chlorophyll-a in continental slope sediments off Cape Hatteras, North Carolina. Deep-Sea Res II 41:767-782

Cahoon LB, Nearhoof JE, Tilton CL (1999) Sediment grain size effect on benthic microalgal biomass in shallow aquatic ecosystems. Estuaries 22:735-741

Capone DG (1993) Detemination of nitrogenase activity in aquatic samples using the acetylene reduction procedure. In: Kemp PF, Sherr BF, Sherr EB, Cole JJ (eds) Handbook of methods in aquatic microbial ecology. Lewis Publishers, Tokyo, p 621-631

Capone DG, Dunham SE, Horrigan SG, Duguay LE (1992) Microbial nitrogen transformations in unconsolidated coral reef sediments. Mar Ecol Prog Ser 80:75-88

> Carr H, Bjork M (2003) A methodological comparison of photosynthetic oxygen evolution and estimated electron transport rate in tropical Ulva (Chlorophyceae) species under different light and inorganic carbon conditions. J Phycol 39:1125-1131

> Cook PLM, Butler ECV, Eyre BD (2004a) Carbon and nitrogen cycling on intertidal mudflats of a temperate Australian estuary. I. Benthic metabolism. Mar Ecol Prog Ser 280: 25-38

Cook PLM, Eyre BD, Leeming R, Butler ECV (2004b) Benthic fluxes of nitrogen in the tidal reaches of a turbid, highnitrate sub-tropical river. Estuar Coast Shelf Sci 59: 675-685

> Dale NG (1974) Bacteria in intertidal sediments: factors related to their distribution. Limnol Oceanogr 19:509-518

Dalsgaard TE, Nielsen LP, Brotas V, Viaroli P and others (2000) Protocol handbook for NICE - Nitrogen Cycling in Estuaries: a project under the EU research programme: Marine Science and Technology (MAST III). National Environmental Research Institute, Silkeborg

de Jong DJ, de Jonge VN (1995) Dynamics and distribution of microphytobenthic chlorophyll-a in the Western Scheldt Estuary (SW Netherlands). Hydrobiologia 311:21-30

Decho AW (1990) Microbial exopolymer secretions in ocean environments - their role(s) in food webs and marine processes. Oceanogr Mar Biol Annu Rev 28:73-153 
Dunstan GA, Volkman JK, Barrett SM, Leroi JM, Jeffrey SW (1993) Essential polyunsaturated fatty acids from 14 species of diatom (Bacillariophyceae). Phytochemistry 35: 155-161

Eilers PHC, Peeters JCH (1988) A model for the relationship between light intensity and the rate of photosynthesis in phytoplankton. Ecol Model 42:199-215

Emery KO (1968) Relict sediments on continental shelves of the world. Am Assoc Petrol Geol Bull 52:445-464

Engelsen A, Hulth S, Pihl L, Sundbäck K (2008) Benthic trophic status and nutrient fluxes in shallow-water sediments. Estuar Coast Shelf Sci 78:783-795

Falkowski P, Raven J (2007) Aquatic photosynthesis, Princeton University Press, Princeton, NJ

Forehead HI (2006) The ecology and biogeochemistry of sandy sediments in the warm temperate coastal waters of Western Australia. PhD dissertation, University of Western Australia, Perth

Gagosian RB, Smith SO, Lee C, Farrington JW, Frew NM (1980) Steroid transformations in recent marine sediments. Phys Chem Earth 12:407-419

Gibb SW, Cummings DG, Irigoien X, Barlow RG, Fauzi R, Mantoura C (2001) Phytoplankton pigment chemotaxonomy of the northeastern Atlantic. Deep-Sea Res II 48: 795-823

Giere O, Eleftheriou A, Murison DJ (1988) Abiotic factors. In: Higgins RP, Thiel $\mathrm{H}$ (eds) Introduction to the study of meiofauna. Smithsonian Institution, Washington, DC, p 61-78

Goto N, Mitamura O, Terai H (2001) Biodegradation of photosynthetically produced extracellular organic carbon from intertidal benthic algae. J Exp Mar Biol Ecol 257:73-86

Jaffe R, Mead R, Hernandez ME, Peralba MC, DiGuida OA (2001) Origin and transport of sedimentary organic matter in two subtropical estuaries: a comparative, biomarkerbased study. Org Geochem 32:507-526

> Janssen F, Huettel M, Witte U (2005) Pore-water advection and solute fluxes in permeable marine sediments (II): benthic respiration at three sandy sites with different permeabilities (German Bight, North Sea). Limnol Oceanogr 50: 779-792

Jeffrey SW, Mantoura RFC, Wright SW (1997) Phytoplankton pigments in oceanography: guidelines to modern methods, Vol 10. UNESCO, International Council of Scientific Unions. Scientific Committee on Oceanic Research, Paris

Lukatelich RJ, McComb AJ (1986) Distribution and abundance of benthic microalgae in a shallow southwestern Australian estuarine system. Mar Ecol Prog Ser 27: 287-297

MacIntyre HL, Geider RJ, Miller DC (1996) Microphytobenthos: the ecological role of the 'secret garden' of unvegetated, shallow-water marine habitats. 1. Distribution, abundance and primary production. Estuaries 19: 186-201

- Mackey DJ, Higgins HW, Mackey MD, Holdsworth D (1998) Algal class abundances in the western equatorial Pacific: estimation from HPLC measurements of chloroplast pigments using CHEMTAX. Deep-Sea Res I 45:1441-1468

Mountford P, Greico A (2002) Hope Valley solar radiation. Department of the Environment, Perth

Mundree S, Perissinotto R, Nozais C (2003) Seasonal variations in the vertical distribution of benthic microalgae in the upper sediment of the Mdloti Estuary, South Africa. Bot Mar 46:323-331

Murray RE, Cooksey KE, Priscu JC (1986) Stimulation of bacterial DNA synthesis by algal exudates in attached algalbacterial consortia. Appl Environ Microbiol 52:1177-1182
Nielsen LP (1992) Denitrification in sediment determined from nitrogen isotope pairing. FEMS Microbiol Ecol 86: $357-362$

> Nieuwenhuize J, Maas YEM, Middelburg JJ (1994) Rapid analysis of organic carbon and nitrogen in particulate materials. Mar Chem 45:217-224

- Nilsson P, Jonsson B, Swanberg IL, Sundback K (1991) Response of a marine shallow-water sediment system to an increased load of inorganic nutrients. Mar Ecol Prog Ser 71:275-290

Pearce AF (1991) Eastern boundary currents of the southern hemisphere. J R Soc West Aust 74:35-45

Pearce AF, Lynch MJ, Hanson CE (2006) The Hillarys Transect (1): seasonal and cross-shelf variability of physical and chemical water properties off Perth, Western Australia, 1996-98. Cont Shelf Res 26:1689-1729

Plante R, Plante-Cuny MR, Reys JP (1986) Photosynthetic pigments of sandy sediments on the North Mediterranean coast: their spatial distribution and its effect on sampling strategies. Mar Ecol Prog Ser 34:133-141

Pomory CM, Robbins BD, Lares MT (1995) Sediment grain size preference by the sand dollar Mellita tenuis Clark, 1940 (Echinodermata: Echinoidea): a laboratory study. Bull Mar Sci 56:778-783

> Rasheed M, Badran MI, Huettel M (2003) Particulate matter filtration and seasonal nutrient dynamics in permeable carbonate and silicate sands of the Gulf of Aqaba, Red Sea. Coral Reefs 22:167-177

Redfield AC (1958) The biological control of chemical factors in the environment. Am Sci 46:205-221

Rizzo WM, Dailey SK, Lackey GJ, Christian RR, Berry BE, Wetzel RL (1996) A metabolism-based trophic index for comparing the ecological values of shallow-water sediment habitats. Estuaries 19:247-256

Rysgaard S, Christensen PB, Nielsen LP (1995) Seasonal variation in nitrification and denitrification in estuarine sediment colonized by benthic microalgae and bioturbating infauna. Mar Ecol Prog Ser 126:111-121

> Sass A, Rütters H, Cypionka H, Sass H (2002) Desulfobulbus mediterraneus sp. nov., a sulfate-reducing bacterium growing on mono- and disaccharides. Arch Microbiol 177: 468-474

Shimeta J, Amos CL, Beaulieu SE, Ashiru OM (2002) Sequential resuspension of protists by accelerating tidal flow: implications for community structure in the benthic boundary layer. Limnol Oceanogr 47: 1152-1164

- Sommer U (1996) Nutrient competition experiments with periphyton from the Baltic Sea. Mar Ecol Prog Ser 140: 161-167

Staats N, Stal LJ, de Winder B, Mur LR (2000) Oxygenic photosynthesis as driving process in exopolysaccharide production of benthic diatoms. Mar Ecol Prog Ser 193: 261-269

Stahl-Delbanco A, Hansson LA (2002) Effects of bioturbation on recruitment of algal cells from the 'seed bank' of lake sediments. Limnol Oceanogr 47:1836-1843

Sun MY, Lee C, Aller RC (1993) Laboratory studies of oxic and anoxic degradation of chlorophyll-a in Long Island Sound sediments. Geochim Cosmochim Acta 57:147-157

Sundbäck K (1984) Distribution of microbenthic chlorophyll-a and diatom species related to sediment characteristics. Ophelia Suppl 3:229-246

- Sundbäck K, Linares F, Larson F, Wulff A, Engelsen A (2004) Benthic nitrogen fluxes along a depth gradient in a microtidal fjord: the role of denitrification and microphytobenthos. Limnol Oceanogr 49:1095-1107 
Thompson P, Waite A (2003) Phytoplankton responses to wastewater discharges at two sites in Western Australia. Mar Freshw Res 54:721-735

Thompson PA, Pesant S, Waite AM (2007) Contrasting the vertical differences in the phytoplankton biology of a dipole pair of eddies in the south-eastern Indian Ocean. Deep-Sea Res II 54:1003-1028

Watermann F, Hillebrand H, Gerdes G, Krumbein WE, Sommer U (1999) Competition between benthic cyanobacteria and diatoms as influenced by different grain sizes and temperatures. Mar Ecol Prog Ser 187: 77-87

Watson RJ, Butler ECV, Clementson LA, Berry KM (2005) Flow-injection analysis with fluorescence detection for the

Editorial responsibility: Rodney Forster,

Lowestoft, UK determination of trace levels of ammonium in seawater. J Environ Monit 7:37-42

Western Australia Department of Environmental Protection (1996) Southern Metropolitan Coastal Waters Study (19911994). Report No. 17, Dept of Environmental Protection, Western Australia, Perth, Western Australia

Wright SW, Jeffrey SW, Mantoura RFC, Llewellyn CA, Bjornland T, Repeta D, Welschmeyer N (1991) Improved HPLC method for the analysis of chlorophylls and carotenoids from marine phytoplankton. Mar Ecol Prog Ser 77: 183-196

Wulff A, Vilbaste S, Truu J (2005) Depth distribution of photosynthetic pigments and diatoms in the sediments of a microtidal fjord. Hydrobiologia 534:117-130

Submitted: September 22, 2008; Accepted: July 15, 2010 Proofs received from author(s): September 2, 2010 